\title{
ПРИМЕНЕНИЕ КОМПОЗИЦИОННЫХ \\ ФЛОКУЛЯНТОВ-КОАГУЛЯНТОВ ДЛЯ ОЧИСТКИ ПРИРОДНЫХ ВОД
}

\author{
Кудрявцев П. Г., Кудрявцев Н. П.
}

\section{ВВЕДЕНИЕ}

Коагуляция является важным процессом при очистке природной воды и промышленных сточных вод. В области очистки питьевой воды с древних времен практикуется очищение воды с помощью коагулянтов с использованием различных веществ. Коагуляция является самым распространенным методом очистки природных и сточных вод от основной массы коллоидных, тонкодисперсных и частично растворенных загрязнений. Повсеместное применение минеральных коагулянтов для очистки воды определяется такими факторами:

- высокая коагулирующая способность и адсорбционная способность продуктов гидролиза минеральных коагулянтов;

- способность образовывать нерастворимые соединения с рядом органических и неорганических веществ;

- доступность и низкая стоимость минеральных коагулянтов.

Масштабы применения метода коагуляции увеличились в последние годы и, судя по прогнозам, будут увеличиваться, поэтому актуален поиск путей совершенствования этого метода.

Соли алюминия и железа широко используются в качестве коагулянтов при очистке природных и сточных вод, а также в ряде других отраслей промышленности. Они эффективны для удаления широкого спектра примесей из воды, включая коллоидные частицы, растворенные органические вещества, нефтепродукты и соли тяжелых металлов. Их действие в основном обусловлено такими механизмами:

- нейтрализация заряда отрицательно заряженных коллоидов продуктами катионного гидролиза солей соответствующих металлов;

- включение примесей в осадок аморфного гидроксида за счет процессов адсорбции, ионного обмена и химического соосаждения.

Относительный вклад этих механизмов зависит от таких факторов, как $\mathrm{pH}$, дозировка коагулянта, ионная сила раствора, вид и концентрация вредных примесей. Альтернативными коагулянтами являются продукты, основанные на создании предварительно 
гидролизованных форм алюминия и железа. Эти продукты во многих случаях более эффективны, чем традиционные коагулянты. Следующим перспективным направлением в создании новых веществ для реагентной очистки воды являются композиционные материалы, совмещающие коагуляционные и флоккуляционные функции.

Одним из таких направлений в интенсификации технологии коагуляционной очистки воды является использование композиционных реагентов, к которым относятся исследуемые коагулянты АКФК и ФКФК. Композиционные коагулянты обладают аддитивным и синергетическим действием, что позволит повысить эффективность очистки воды, сократить расходы и количество применяемых реагентов, упростить технологию их применения.

Низкомолекулярные неорганические или органические электролиты, приводящие к агрегации частиц, называются коагуляторами. Частным случаем коагуляторов являются коагулянты гидролизующиеся соли, например сульфаты и галогениды многозарядных катионов (алюминия, железа, титана и др.). К флокулянтам относятся неорганические или органические высокомолекулярные химические соединения, которые способствуют образованию агрегатов при осаждении частиц дисперсной системы. Эти вещества действуют за счет объединения нескольких частиц с помощью макромолекул полимера, который адсорбируется или химически связывается с поверхностью частиц дисперсной системы ${ }^{1}$.

Н.Е. Кручининой и В. Ким с соавторами разработан способ обработки нефелина серной кислотой ${ }^{2,3}$, в результате чего образуется жидкий алюмокремниевый флокулянт-коагулянт (АКФК). Это способ получения алюмосиликатного коагулянта, в котором алюмосиликатное сырье обрабатывают раствором серной кислоты, а в полученный раствор вводят стабилизирующую добавку. Недостатками этого способа являются недостаточный срок хранения готового продукта, сложность процесса, использование стабилизирующих полимерных добавок и значительные энергозатраты при его изготовлении.

Алюмокремниевый флокулянт-коагулянт АКФК является одной из немногих бинарных композиций, в состав которой входят только неорганические компоненты, такие как коагулянт - сульфат алюминия и

1 Запольский А.К., Баран А.А. Коагулянты и флокулянты в процессах очистки воды. Свойства. Получение. Применение. Ленинград : Химия, 1987, 208 с.

2 Кручинина Н.Е., Турниер В.Н., Лисюк Б.С., Ким В. Способ получения алюмосиликатного коагулянта. Пат. РФ № 2225838, 26.11.02.

3 Кручинина Н.Е. АКФК как альтернатива традиционным коагулянтам в процессах водоочистки и водоподготовки. Экология производства. 2006. № 2. C. $46-50$. 
анионный флокулянт - активная кремниевая кислота. Действие АКФК основано на результате взаимодействия его первичных компонентов. Первичными компонентами являются коагулянт - соединение алюминия и флокулянт - активная кремниевая кислота. При взаимодействии исходных компонентов образуются комплексные соединения, обладающие более высокой флоккулирующей способностью. Образующиеся продукты представляют собой цеолитоподобные наноразмерные структуры с развитой сорбционной поверхностью. Такое сочетание исходных продуктов приводит к синергетическому эффекту, который заключается в возрастании эффективности воздействия в результате интеграции отдельных процессов в единую систему. Механизм очистки воды реализуется за счет объемной сорбции загрязнителей на самоорганизующихся алюмокремниевых комплексах.

Ввиду нестабильности продукта, получаемого растворением нефелинового сырья, перед авторами стояла задача разработки способа получения алюмокремниевого флокулянта-коагулянта в виде кристаллического продукта, который обладает более высокой стабильностью, длительным сроком хранения. Он должен быть прост в изготовлении и экономичен при транспортировке, иметь более высокое содержание активной составляющей. Также он должен быть эффективным и простым при использовании для очистки сточных вод. Авторам удалось решить эту задачу, совместив в твердой фазе все активные компоненты этого материала ${ }^{4}$.

В основу разработанного метода синтеза были заложены принципы, лежащие в основе известного метода матричной изоляции, получившей развитие в конце прошлого века. Метод матричной изоляции позволяет замораживать и изучать реакционноспособные частицы с коротким временем жизни в инертной твердой матрице. Как известно, межмолекулярное взаимодействие наиболее сильно проявляется в случае химически активных частиц. Такими частицами является большинство атомов, свободных радикалов и молекул, которые находятся в мономерном состоянии только при высоких температурах. Подобные частицы можно исследовать только в газовой фазе и только при низкой концентрации. Однако даже в таких экстремальных условиях некоторые частицы настолько реакционноспособны, что способны существовать только очень короткое время после образования, поэтому изучение их молекулярных свойств весьма затруднено.

${ }^{4}$ Недугов А.Н., Волкова М.А., Кайсин А.В., Кудрявцев П.Г., Кудрявцев Н.П., Порошина Н.В., Рябов В.А. Способ получения композиционного алюмокремниевого флокулянта-коагулянта. Патент РФ № 2447021, по заявке № 2010133345/05, МПК, С01B33/26, C02F1/52, C01F7/74. Бюл. 09.08.2010. 
Метод матричной изоляции возник как попытка преодолеть указанные выше трудности при исследовании реакционноспособных молекул. Он заключается в замораживании изучаемых молекул в жестком окружении (матрице) химически инертного вещества при низких температурах. Жесткость матрицы препятствует диффузии активных молекул, то есть затрудняет их взаимодействие с другими подобными частицами. Инертность матричного вещества необходима для предотвращения взаимодействия активных частиц с матрицей5. Такая ситуация прослеживается и при получении алюмокремниевых флокулянтовкоагулянтов.

Использование подобных технологических приемов позволило «заморозить» и изолировать в матрице в твердой фазе компоненты флокулянта-коагулянта, а именно кислые соли сульфата алюминия и активную кремниевую кислоту, находящуюся в нанодисперсном состоянии или в форме полимерных силикатов щелочных металлов. Быстрый перевод активных компонентов в твердое состояние позволяет резко снизить скорости диффузионных процессов и сохранить активность материала. При развитии этого метода были получены не только алюмокремниевые флокулянты-коагулянты, но и железокремниевые материалы. Таким материалам было присвоено условное наименование «ЖКФК» ${ }^{6}$. Изучению влияния условий синтеза этих материалов и их применению для очистки сточных вод от нефтепродуктов и солей тяжелых металлов был посвящен целый цикл работ $7,8,9,10,11,12,13,14,15,16,17,18,19,20$.

${ }^{5}$ Cradock S., Hinchcliffe A.J. Matrix Isolation. A Technique for the Study of Reactive Inorganic Species, Cambridge Universrty Press, Cambridge, 1975.

${ }^{\circ}$ Недугов А.Н., Волкова М.А., Кайсин А.В., Кудрявцев П.Г., Кудрявцев Н.П., Порошина Н.В., Рябов В.А. Способ получения железокремниевого флокулянтакоагулянта и способ обработки воды, Патент РФ № 2438993, по заявке № 2010133344/05, МПК, C02F1/52, C01G49/14, C01B33/32, В01D21/01. Бюл. 09.08.2010.

7 Кудрявцев П.Г., Недугов А.Н., Рябов В.А., Волкова М.А., Кайсин А.В., Коротаев И.М., Коркин А.М. Способ получения алюмокремниевого флокулянтакоагулянта и способ очистки с его помощью воды. Патент РФ № 2388693 МПК, C01B33/26, C01F7/74, С02F1/52. Бюл. 28.07.2008.

8 Волкова М.А., Дегтев М.И., Кудрявцев П.Г., Недугов А.Н., Кайсин А.В., Андриенко С.В. Новый высокотехнологичный алюмокремниевый флокулянт-коагулянт как альтернатива известным реагентам водоочистки. Актуальные проблемы химической науки, практики и образования : сборник статей Международной научно-практической конференции, 19-21 мая 2009 г. Ч. 2. С. 19-22.

Волкова М.А., Дегтев М.И., Кудрявцев П.Г., Недугов А.Н., Кайсин А.В., Андриенко С.В. Новый высокотехнологичный алюмокремниевый флокулянткоагулянт как альтернатива известным реагентам водоочистки. Сборник трудов ЕНИ при ПГУ. Пермь, 2010. С. 41-43.

${ }_{10}$ Kudryavtsev P.G., Kudryavtsev N.P., Nedugov A.N., Volkova M.A., Kudryavtsev I.P. Solid Alumina-Silicon Flocculants-Coagulants - Matrixisolated Nanocomposites. Technical chemistry, from theory to practice : IV International Conference, October 20-24, 2014. Perm. P. 38. DOI: 10.13140/RG.2.1.2195.7283. 
В связи с этим целью работы является сравнение эффективности применения композиционных реагентов АКФК и ЖКФК и традиционных коагулянтов, а именно сульфата алюминия и железного купороса, которые являются компонентами исследуемых композиционных коагулянтов, для очистки природных вод.

\section{1. Обоснование выбранного направления исследований}

Гидролизующие соли металлов на основе алюминия или железа очень широко используются в качестве коагулянтов при обработке воды. Древние римляне также были знакомы с квасцами. Квасцы, или сульфат алюминия, использовались ими для очистки воды с древних

${ }^{11}$ Kudryavtsev P.G., Kudryavtsev N.P., Kudryavtsev I.P. Nanocomposite aluminasilica-flocculants-coagulants, Current Issues of Ecological Safety: Cleaning of Water Sources and Air Basin; Recycling of Municipal Solid Waste, Book of Abstracts, p. 11, 2015, Jerusalem.

12 Kudryavtsev P.G., Kudryavtsev N.P. New high-tech composite flocculantscoagulants as an alternative to the known reagents for water treatment. Alternative Energy and Ecology (ISJAEE). 2016. № 11-12 (199-200). P. 93-103. DOI: 10.15518/isjaee.2016.11-12.093-103.

${ }^{13}$ Kudryavtsev P.G., Kudryavtsev N.P. New Composite Flocculants - Coagulants as an Alternative to the Known Water Treatment Agents. Scientific Israel-Technological Advantages. 2016. Vol. 18. № 3. P. 84-97.

${ }^{14}$ Kudryavtsev P.G., Kudryavtsev N.P. Matrix-isolated nanocomposites - aluminasilicon flocculants-coagulants, 34th IVS Annual Meeting, September 12th, 2016, Ben Gurion University of the Negev, Beer-Sheva. P. 112.

15 Kudryavtsev N., Kudryavtsev P., Figovsky O.L. Matrix-Isolated Smart Nanocomposite Materials - Alumina Silicon Flocculants Coagulants, 4th International Conference on Competitive Materials and Technology Processes, Miskolc-Lillafüred, Hungary, October 3-7, 2016. P. 134.

16 Kudryavtsev P.G., Kudryavtsev N.P., Figovsky O.L. Matrix-isolated nanocomposite flocculants, coagulants for purification of natural and waste waters from oil pollution. NANOTECHOILGAS - 2016 : Proceedings of the V International Scientific and Practical Conference, Moscow, November 22-24, 2016. Moscow : Oil \& Gas, 2016. P. 91-96.

${ }^{17}$ Кудрявцев П.Г., Кудрявцев Н.П., Фиговский О.Л. Очистка промышленных и сточных вод с использованием матрично-изолированных нанокомпозиционных флокулянтов-коагулянтов. Нанотехнологии в строительстве. 2017. Vol. 9. №. 3. C. 44-61. DOI: dx.doi.org/10.15828/2075-8545-2017-9-3-44-61.

${ }^{18}$ Kudryavtsev P., Figovskiy O. Matrix-Isolated Nanocomposites - Alumina-Silicon Flocculants-Coagulants. Journal of Physical Science and Application. 2017. Vol. 7. № 3. P. 25-36. DOI: 10.17265/2159-5348/2017.03.003.

${ }^{19}$ Kudryavtsev P., Figovsky O., Kudryavtsev N. Cleaning of natural and sewage water using new composite flocculantscoagulants. Engineering Journal of Don. 2017. № 4. P. 1-18. ISSN 2073-8633, ivdon.ru/ru/magazine/archive/n4y2017/4572.

${ }^{20}$ Кудрявцев П.Г., Кудрявцев Н.П. Очистка сточных вод с использованием матрично-изолированных нанокомпозиционных флокулянтов-коагулянтов. Инженерный вестник Дона. 2018. № 3. С. 1-32. ISSN 2073-8633, ivdon.ru/ru/ magazine/archive/n3y2018/5045. 
времен и впервые были упомянуты Плинием (около 77 года н. э.) ${ }^{21}$. К 1757 году квасцы использовались в качестве коагулянта при обработке воды в Англии, а в 1881 году более формально при обработке воды для общественных нужд 22 В современной обработке воды коагуляция и флокуляция все еще являются важными этапами в процессах очистки различных видов природных и сточных вод.

Трехвалентные соли алюминия и железа стали применяться для коагуляции дисперсных загрязнений практически во всех водоочистных системах после того, как было установлено, что эффект коагуляции увеличивается с увеличением валентности коагулирующего иона. К настоящему времени накоплен большой экспериментальный материал по использованию коагулянтов для очистки природных вод, который нашел отражение в многочисленных публикациях и монографиях ${ }^{23,24,25,26,27,28,29,30,31,32,33,34}$.

${ }^{21}$ Cohen J.M., Hannah S.A. Coagulation and flocculation, Water Quality and Treatment. Handbook of Public Water Supplies. 3d ed. McGraw-Hill BookCompany, New York, 1971. P. 66-122.

22 Bratby J. Coagulants. Coagulation and Flocculation in Water and Wastewater Treatment. 2nd ed. IWA Publishing, London, 2006. P. 50-68.

${ }^{23}$ Драгинский В.Л., Алексеева Л.П., Гетманцев С.С. Коагуляция в технологии очистки природных вод. Москва, 2005. 571 с.

${ }^{24}$ Кульский Л.А., Строкач П.П. Технология очистки природных вод. Киев : Высшая школа, 1986. 352 с.

${ }^{25}$ Tipping, E WHAM - a chemical equilibrium model and computer code for waters, sediments, and soils incorporating a discrete site/electrostatic model of ion-binding by humic substances. Computers and Geosciences. 1994. № 20 (6). P. 973-1023. DOI: 10.1016/0098-3004(94)90038-8.

${ }^{26}$ Бабенков Е.Д. Очистка воды коагулянтами. Москва : Наука, 1977. 355 с.

27 Линевич С.Н., Гетманцев С.В. Коагуляционный метод водообработки. Теоретические основы и практическое использование. Москва : Наука, 2007. 230 с.

${ }^{28}$ Драгинский В.Л. Повышение эффективности реагентной обработки воды на водопроводных станциях. ВСТ / Водоснабжение и санитарная техника. 2000. № 5. С. 11.

29 Гетманцев С.В. Состояние производства и импорта алюмосодержащих коагулянтов в России. ВСТ / Водоснабжение и санитарная техника. 2003. № 2. С. 5.

${ }_{30}$ Коагулянты и флокулянты: анализ и оценка современного технологического уровня производства: Аналитический обзор. Черкассы : Черкасский НИИТЭХИМ, 2001. 37 c.

${ }^{31}$ Гетманцев С.В., Мясников И.Н., Потанина В.А., Сычев А.В. Использование алюмосодержащих коагулянтов в Северо-Западном федеральном округе. Сообщение 2. Технология применения полиоксихлоридов алюминия для доочистки воды. Вода и экология. 2002. № 2. С. 2.

32 Гумен С.Г., Дариенко И.Н., Евельсон Е.А., Русанова П.П. Применение современных химических реагентов для обработки маломутных цветных вод. ВCT / Водоснабжение и санитарная техника. 2001. № 3. С. 12.

33 Храменков С.В., Благова О.Е. Использование современных коагулянтов и флокулянтов в системе Московского водопровода. Водоснабжение и санитарная техника. 2001. № 3. С. 5. 
Классическим коагулянтом для очистки природных вод, который до последнего времени применялся на водопроводах России, является сернокислый алюминий. Применение сульфата алюминия обусловлено его высокой коагулирующей, адсорбционной и осадительной способностью данного реагента и продуктов его гидролиза касательно большинства загрязнений природных вод, доступностью и низкой стоимостью. Однако сернокислый алюминий имеет ряд недостатков, главными из которых являются низкая эффективность и высокое содержание остаточного алюминия при низких температурах. Сульфат железа (II) применяется реже при водоподготовке вследствие необходимости создания специальных условий (введения окислителя, подщелачивание) для перевода двухвалентного железа в трехвалентное и поддержания нормируемого содержания остаточного железа в очищенной воде $\mathrm{e}^{35}$.

При использовании сульфата алюминия (СА) для увеличения эффективности очистки воды применяют различные флокулянты. Наибольшее применение получили такие флокулянты, как активная кремниевая кислота и полиакриламид (ПАА ${ }^{36}$. В последние годы с увеличением рыночного ассортимента флокулянтов в водоподготовке стали применять катионные органические коагулянты, например ВПК 402, и высокомолекулярные катионные флокулянты, например Праестол $650^{37}$.

Активная кремниевая кислота (АКК) имеет ряд преимуществ по сравнению с ПАА, главными из которых являются отсутствие токсичности и вторичных загрязнений воды органическими веществами, наличие доступной сырьевой базы, поэтому в водоподготовке с 60-х годов сульфат алюминия стал использоваться в сочетании с активной кремниевой кислотой ${ }^{38}$.

Главными недостатками активной кремниевой кислоты, растворы которой проявляют свойства анионного полиэлектролита, являются неустойчивость и склонность к гелеобразованию при хранении ${ }^{39}$, поэтому активную кремниевую кислоту в виде разбавленных водных растворов получают непосредственно на очистной станции путем

34 Герасимов Г.Н. Процессы коагуляции-флокуляции при обработке поверхностных вод. ВСТ / Водоснабжение и санитарная техника. 2001. № 3. С. 26.

${ }_{35}$ Клячко В.А., Апельцин И.Э. Очистка природных вод. Москва, 1971. С. 579.

36 Вейцер Ю.И., Минц Д.М. Высокомолекулярные флокулянты в процессах очистки природных и сточных вод. Москва : Стройиздат, 1984. 201 с.

${ }^{37}$ Аксенов В.И., Гандурина Л.В., Керин А.С. и др. Водное хозяйство промышленных предприятий. Кн. 6 : Флокулянты. Москва : Теплотехник, 2008. С. 256.

${ }^{38}$ См. сноску 36.

${ }^{39}$ См. сноску 36. 
взаимодействия (активации) растворов силиката натрия с кислотами или кислыми солями алюминия или железа. Процесс протекает в 2 стадии. Сначала происходит реакция активации жидкого стекла, имеющего щелочную реакцию, кислыми реагентами с получением кремниевой кислоты. Затем образующаяся кремниевая кислота $\mathrm{H}_{4} \mathrm{SiO}_{4}$ благодаря наличию реакционноспособных силанольных групп $\mathrm{SiOH}$ вступает в реакцию поликонденсации по такой схеме:

$$
2 \mathrm{Si}(\mathrm{OH})_{4} \rightarrow \mathrm{OH}-\left\{\mathrm{Si}(\mathrm{OH})_{2}-\mathrm{O}-\mathrm{Si}(\mathrm{OH})_{2}\right\}_{n}-\mathrm{OH}+\mathrm{H}_{2} \mathrm{O} .
$$

В результате этого образуются поликремневые кислоты с линейной, разветвленной или смешанной структурой, которые одни авторы рассматривают как коллоидные частицы, склонные к коагуляции при хранении, а другие - как растворимые полиэлектролиты, способные к образованию нерастворимых сетчатых структур и гелеобразованию, поэтому часто процесс поликонденсации называют процессом созревания золя активной кремневой кислоты.

В большинстве рекомендаций по получению активной кремниевой кислоты применяют $1,2 \div 1,7 \%$ раствор силиката натрия (по $\mathrm{SiO}_{2}$ ) и проводят его нейтрализацию $20 \%$ серной кислотой или $1,5 \div 2,5 \%$ сульфатом алюминия до $\mathrm{pH}-7-8$. Процесс поликонденсации - это созревание золей. Его контролируют по увеличению вязкости или увеличению мутности раствора, а заканчивают через $60 \div 120$ мин. После завершения процесса для продления срока годности активированной кремниевой кислоты золь разбавляют водой до получения раствора с концентрацией $0,5 \div 0,75 \%$ по $\mathrm{SiO}_{2}$.

Скорость поликонденсации зависит от $\mathrm{pH}$ и минимальна при $\mathrm{pH}$ $2 \div 3$. Устойчивость раствора активной кремниевой кислоты к коагуляции максимальна при $\mathrm{pH}>7,5$. Скорость гелеобразования

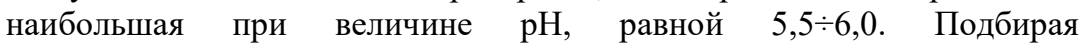
соответствующие условия и применяя специальные добавки (стабилизаторы), можем увеличить устойчивость и концентрацию растворов активной кремниевой кислоты.

Более перспективным является применение смеси реагентов, состоящей из сульфата алюминия и силиката натрия. В частности, рекомендуют $1 \%$ раствор силиката натрия смешивать с $1 \%$ раствором сернокислого алюминия в соотношении 1:4, а полученный раствор сразу применять в качестве коагулянта.

В последние годы разрабатываются порошковые и жидкие кремниевые и алюмокремниевые коагулянты, обладающие повышенной устойчивостью и концентрацией. Например, в Институте биоорганической химии и нефтехимии АН Украины разработаны неорганические реагенты серии «Сизол» на основе стабилизированного 
золя кремнезема $\left(20 \%\right.$ по $\left.\mathrm{SiO}_{2}\right)$. Разработанный реагент устойчив в областях $\mathrm{pH}$, близких к нейтральному, тогда как нестабилизированный золь кремниевой кислоты быстро превращается в гель ${ }^{40}$.

Как уже отмечалось, авторами ${ }^{41,42,43}$ был разработан жидкий композиционный алюмокремниевый флокулянт-коагулянт (АКФК). Его получали из алюмосиликатного минерала нефелина путем его обработки раствором серной кислоты. Получаемый таким образом продукт можно рассматривать как смесь сернокислого алюминия и активной кремниевой кислоты либо как поли-окси-силикат-сульфат алюминия. Он образуется в результате полимеризации первичных гидроксокомплексов алюминия. Такие полиядерные гидроксокомплексы ${ }^{44,45}$ образуются в растворах кислых и основных солей алюминия благодаря высоким комплексообразующим свойствам алюминия. К настоящему времени идентифицированы гидроксокомплексы с содержанием атомов алюминия от 6 до 54: $A l_{6}(\mathrm{OH})_{12}^{6+}, A l_{10}(\mathrm{OH})_{22}^{8+}, A l_{24}(\mathrm{OH})_{60}^{12+}, A l_{54}(\mathrm{OH})_{144}^{18+}$. В полиядерных гидроксокомплексах ионы алюминия связаны между собой мостиковыми ОН-группами (оловые связи) или О-мостиками (оксосвязи). Однако не все подобные комплексы реально образуются при гидролизе солей алюминия.

Диаграмма областей существования для различных состояний иона алюминия (III), относящаяся к ионной силе 1,0 моль/кг хлорида, показана на рис. 1 , где предполагаемой твердой фазой является кристаллический гиббсит, а именно $\mathrm{Al}(\mathrm{OH})_{3(\mathrm{~s})}$. Эта диаграмма показывает, что низкая ионная сила и высокая температура способствуют образованию мономерных частиц ионов металлов. Диаграмма также показывает, что преобладающей твердой фазой, особенно из-за ненасыщенности, является аморфный гидроксид алюминия $\mathrm{Al}(\mathrm{OH})_{3(\mathrm{am})}$. Было обнаружено, что, в отличие от многих других ионов металлов, для алюминия существует ограниченная область, где преобладают полимерные продукты гидролиза алюминия (III).

40 Новикова И.А., Бортышевский В.А., Кашковский В.И., Войновский В.В. Использование высокоэффективных коагулянтов при очистке воды. Экотехнологии и ресурсосбережение. 2002. № 3. С. 52.

${ }^{41}$ См. сноску 2.

${ }^{42}$ См. сноску 3.

${ }^{43}$ Кручинина Н.Е., Тимашева Н.А., Шибеши А.К., Волкова И.И., Васильева Е.С. Алюмокремниевые флокулянты-коагулянты в очистке сточных вод пищевой промышленности. Вода: экология $u$ технология : тезисы. Москва : УН Международный конгресс, 2006. С. 603.

${ }^{44}$ См. сноску 1.

45 Розенталь О.М., Кардашина Л.Ф. Химия, технология и сертификация неорганических материалов, применяемых в водном хозяйстве. Екатеринбург : УрО РАH, 1998. $252 \mathrm{c}$. 
Данные, приведенные в работе ${ }^{46}$, показывают, что константа растворимости для $\mathrm{Al}(\mathrm{OH})_{3(\mathrm{am})} \mathrm{pK}_{\mathrm{s}}=10,38$ в 0,1 М растворе хлорида натрия. Растворимость для кристаллического гиббсита примерно на два порядка меньше $\left(\mathrm{pK}_{\mathrm{s}}=8,34\right)$. Предположение, что $\mathrm{Al}(\mathrm{OH})_{3(\mathrm{am})}$ является твердой фазой, приводит к относительно большой области стабильности для полимерных ионов $\left[\mathrm{Al}_{13}(\mathrm{OH})_{32}\right]^{7+}$. В показано, что доминирующими компонентами растворов солей алюминия (III) были ионы $\mathrm{Al}^{3+}, \quad[\mathrm{AlOH}]^{2+}, \quad\left[\mathrm{Al}_{13}(\mathrm{OH})_{32}\right]^{7+}$ и

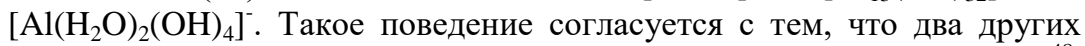
полимерных вида могут быть только второстепенными видами ионов ${ }^{48}$. Более детальный обзор исследований, посвященных состоянию ионов алюминия (III) в водных растворах при гидролизе, представлены в нашей работе ${ }^{49}$.

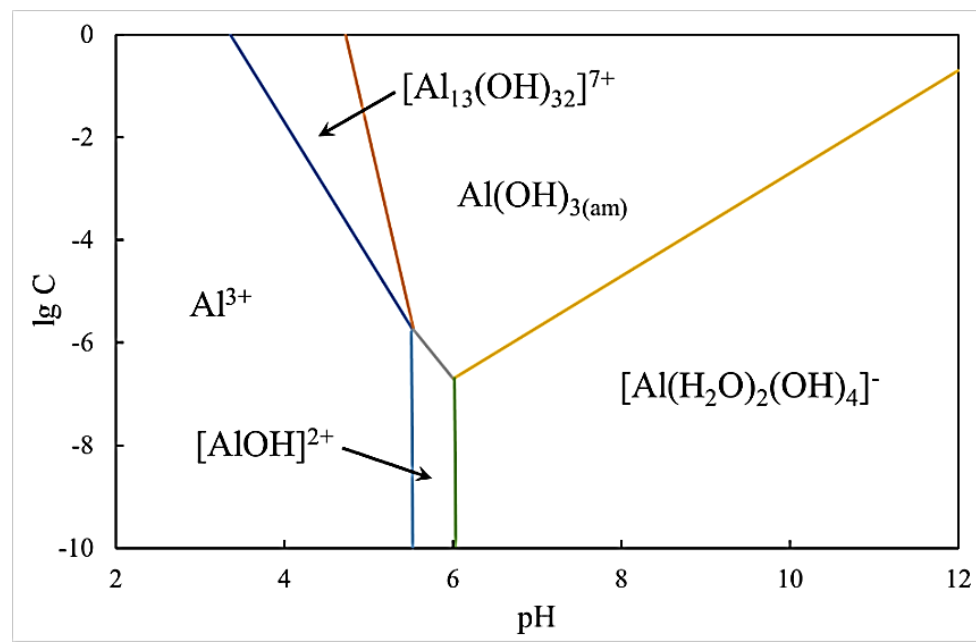

Рис. 1. Диаграмма областей существования для различных состояний иона алюминия (III) при $25^{\circ} \mathrm{C}$ в растворе с ионной силой 1,0 моль $\mathrm{NaCl} /$ кг

${ }^{46}$ Brown P.L., Ekberg C. Hydrolysis of Metal Ions. Vol. 2. 2016. Wiley-VCH Verlag GmbH \& Co., 945 p. ISBN: 978-3-527-33010-2

${ }^{47}$ См. сноску 22.

${ }^{48}$ Baes C.F., Mesmer, R.E. The Hydrolysis of Cations. New York : John Wiley \& Sons, Inc., 1976.

${ }^{49}$ Kudryavtsev P. Aluminum Hydroxide Based Anion Exchange Materials. Scientific Israel-Technological Advantages. 2019. Vol. 22. No. 1. P. 44-68. 
Константы стабильности и растворимости, полученные при $25^{\circ} \mathrm{C}$ для нулевой ионной силы, были использованы для создания диаграммы областей существования для различных состояний иона железа (II). Диаграмма состояний иона железа (II) представлена на рис. 2. Диаграмма основана на предположении, что доминирует твердая фаза $\mathrm{Fe}(\mathrm{OH})_{2(s)}$. Однако эта твердая фаза контролирует растворимость только в относительно небольшой области ${ }^{50}$. Гидролиз солей железа в растворах изучен методом катионного обмена, определены константы гидролиза $\mathrm{pK}_{1}=6,90$ и $\mathrm{pK}_{2}=8,25$. Исходя из этих данных, мы построили диаграмму распределения гидроксокомплексов железа (II) в зависимости от $\mathrm{pH}$ раствора (рис. 2).

Гидролиз железа (II) по первой ступени начинается при $\mathrm{pH} \approx 5$ и наиболее полно протекает при $\mathrm{pH}$ начала осаждения гидроксида железа

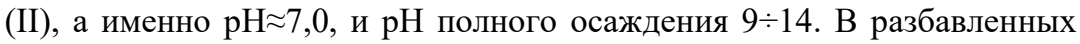
растворах солей железа (II) гидролиз протекает по таким схемам:

$$
\begin{gathered}
\mathrm{Fe}^{2+}+\mathrm{H}_{2} \mathrm{O} \leftrightarrow \mathrm{FeOH}^{+}+\mathrm{H}^{+} ; \\
\mathrm{FeOH}^{+}+\mathrm{H}_{2} \mathrm{O} \leftrightarrow \mathrm{Fe}(\mathrm{OH})_{2(a q)}+\mathrm{H}^{+} ; \\
\mathrm{Fe}(\mathrm{OH})_{2(a q)}+\mathrm{H}_{2} \mathrm{O} \leftrightarrow\left[\mathrm{Fe}\left(\mathrm{H}_{2} \mathrm{O}\right)_{3}(\mathrm{OH})_{3}\right]^{-}+\mathrm{H}^{+} .
\end{gathered}
$$

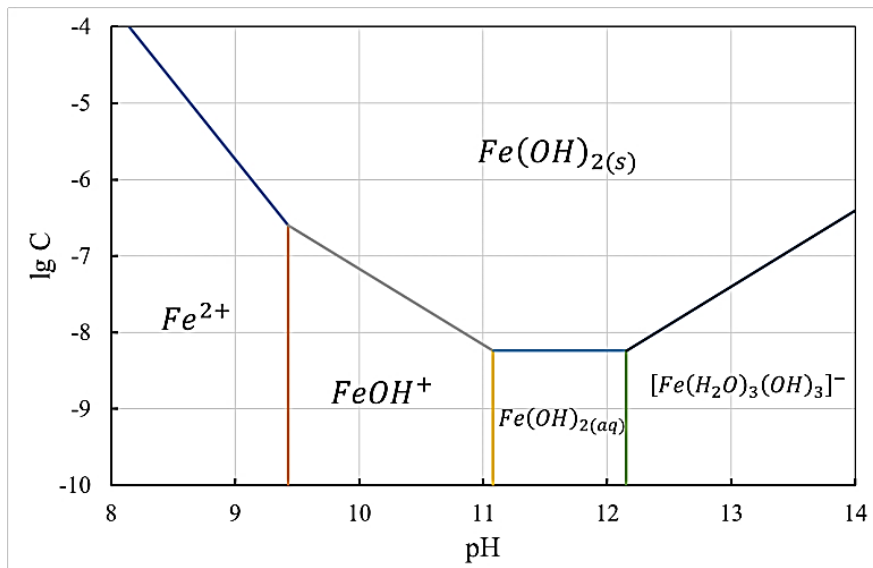

Рис. 2. Диаграмма областей существования для различных состояний иона железа (II) при $25^{\circ} \mathrm{C}$

${ }^{50}$ Brown P.L., Ekberg C. Hydrolysis of Metal Ions. Vol. 2. Wiley-VCH Verlag GmbH \& Co., 2016. 945 p. ISBN: 978-3-527-33010-2. 
Активная кремниевая кислота является наиболее распространенным неорганическим флокулянтом. Она получается путем конденсации низкомолекулярных кремниевых кислот или их труднорастворимых солей. Активная кремниевая кислота представляет собой анионный полиэлектролит. Свойства растворов активной кремниевой кислоты характеризуются такими параметрами, как степень полимеризации макромолекул, размер частиц, изоэлектрическая точка. Они зависят от способов получения этих растворов, продолжительности и условий хранения и других факторов. Приготовление активной кремниевой кислоты состоит из таких стадий ${ }^{51}$ :

1) разложение силикатов натрия с выделением кремниевых кислот (активация жидкого стекла);

2) полимеризация (поликонденсация) кремниевых кислот с образованием высокомолекулярных продуктов (созревание активной кремниевой кислоты);

3) остановка процессов полимеризации полученной активной кремниевой кислоты с целью предотвращения их дальнейшего гелеобразования.

Основные равновесия в системе, которые представлены на рис. 3, имеют такой вид ${ }^{52}$ :

$$
\begin{gathered}
\mathrm{SiO}_{2}+2 \mathrm{H}_{2} \mathrm{O} \leftrightarrow \mathrm{Si}(\mathrm{OH})_{4} ; \\
\mathrm{Si}(\mathrm{OH})_{4}+\mathrm{OH}^{-} \leftrightarrow \mathrm{SiO}(\mathrm{OH})_{3}^{-}+\mathrm{H}_{2} \mathrm{O} ; \\
\mathrm{SiO}(\mathrm{OH})_{3}^{-}+\mathrm{OH}^{-} \leftrightarrow \mathrm{SiO}_{3}^{2-}+\mathrm{H}_{2} \mathrm{O} .
\end{gathered}
$$

При $\mathrm{pH}$ 10,5 общая концентрация растворимого кремнезема может быть объяснена присутствием $\mathrm{Si}(\mathrm{OH})_{4}$ и $\mathrm{SiO}(\mathrm{OH})_{3}^{-}$и, вероятно, небольшим количеством ионов $\mathrm{SiO}_{3}^{2-}$. Таким образом, никакие другие ионные разновидности не могут присутствовать в заметных количествах в таких растворах.

${ }^{51}$ Kudryavtsev P., Figovsky O. Nanomaterials based on soluble silicates : monograph. LAP Lambert Academic Publishing, 2014. 241 p. ISBN 978-3-659-63556-4.

${ }^{52}$ Sjöberg S.; Nordin A.; Ingri N. Equilibrium and structural studies of silicon (IV) and aluminium(III) in aqueous solution. II. Formation constants for the monosilicate ions $\mathrm{SiO}(\mathrm{OH})_{3}{ }^{-}$and $\mathrm{SiO}_{2}(\mathrm{OH})_{2}{ }^{2-}$. A precision study at $25^{\circ} \mathrm{C}$ in a simplified seawater medium. Marine Chemistry. 1981. Vol. 10. Issue 6. P. 521-532. DOI: https://doi.org/10.1016/03044203(81)90005-0. 


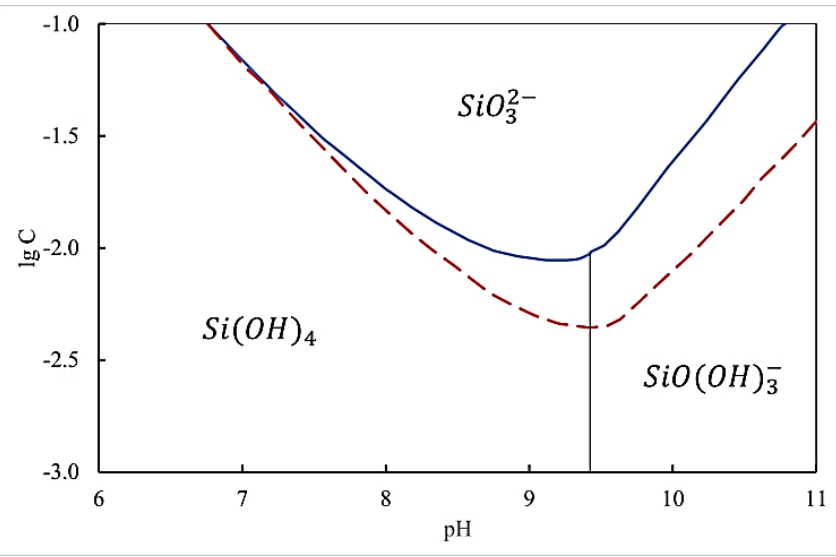

Рис. 3. Диаграмма областей существования для различных состояний иона кремния (IV) при $25^{\circ} \mathrm{C}$ (пунктирная кривая соответствует данным для кварца $(\mathrm{pKs}=4)$, сплошная - для аморфного оксида кремния $(\mathrm{pKs}=2,76))$

Полимеризация активной кремниевой кислоты начинается в области $\mathrm{pH}$ 2-7. Ее полимеризацию в растворе в областях $\mathrm{pH}$ ниже и выше 7 необходимо рассматривать отдельно по таким причинам ${ }^{53}$.

1) Только при низких значениях $\mathrm{pH}$ полимеризация протекает достаточно медленно, что позволяет проследить ее на ранних стадиях. Соответствующие изменения, которые происходят в течение нескольких часов при $\mathrm{pH} \mathrm{2,} \mathrm{завершаются} \mathrm{за} \mathrm{несколько} \mathrm{минут} \mathrm{или}$ секунд при $\mathrm{pH} 8-9$.

2) Дискретные полимерные единицы или частицы, сформированные при низких $\mathrm{pH}$, не несут заряда. Исключение составляет только случай очень низкой концентрации кремнезема. При образовании полимерных частиц начинает происходить их агрегация. Агрегация частиц происходит по двум причинам. Первая причина обусловлена отсутствием заряда на поверхности частиц. Вторая причина связана с чрезвычайно малым размером этих частиц. Частицы активной кремниевой кислоты прекращают свой рост при достижении размера около 2-3 нм. Так как скорость процесса агрегации зависит главным образом от числа частиц в единице объема суспензии и в меньшей степени от размера частиц, такой процесс происходит даже при очень низких концентрациях кремнезема.

${ }^{53}$ Айлер Р. Химия кремнезема. Т. 1-2. Москва : Мир, 1982. 1127 с. 
3) При $\mathrm{pH}>7$ каждая индивидуальная частица продолжает расти вплоть до некоторого большего размера, зависящего в основном от температуры процесса. Агрегация частиц и гелеобразование накладываются на этот процесс. Эти процессы происходят в присутствии какого-либо электролита в количестве, близком к критической концентрации коагуляции. В этом случае наблюдается более высокая ионизация полимерных частиц. В подобной системе полимеризация мономера происходят очень быстро, возможно, даже за несколько минут, a также происходит понижение его концентрации. В то же время частицы кремнезема быстро вырастают до определенного размера, зависящего в первую очередь от температуры, но никакой агрегации или соединения частиц вместе в цепочки не происходит, поскольку частицы являются заряженными и взаимно отталкиваются.

Поскольку композиционные флокулянты-коагулянты типа АКФК состоят из двух основных компонентов активной кремниевой кислоты и соли алюминия, то необходимо рассмотреть вопросы их взаимодействия в водных растворах.

В своей классической монографии ${ }^{54}$ Р. Айлер отмечал, что мономерный кремнезем вступает в реакцию с ионами $\mathrm{A} 1^{3+}$ и наиболее эффективно осаждается при $\mathrm{pH}$ 9. Если реакция мономерного кремнезема $\mathrm{Si}(\mathrm{OH})_{4}$ с ионами $\mathrm{A}^{3+}$ протекает в течение длительного времени при $25^{\circ} \mathrm{C}$, то образуется силикат алюминия в коллоидной форме с составом, соответствующим минералу галлоизиту:

$$
2 \mathrm{Si}(\mathrm{OH})_{4}+\mathrm{Al}^{3+}+\mathrm{H}_{2} \mathrm{O} \leftrightarrow \mathrm{Al}_{2} \mathrm{Si}_{2} \mathrm{O}_{5}(\mathrm{OH})_{4}+6 \mathrm{H}^{+} .
$$

Мономерный кремнезем сильно адсорбируется на поверхности гидроксида алюминия. В результате реакции между $\mathrm{Si}(\mathrm{OH})_{4}$ и $\mathrm{Al}(\mathrm{OH})_{3}$ образуется несколько слоев кремнезема на поверхности гидроксида алюминия. При этом наблюдается понижение $\mathrm{pH}$ суспензии $^{55}$. Образование первого слоя происходит быстро, но второй и третий слои достраиваются гораздо медленнее. Вероятно, с поверхности твердой фазы $\mathrm{Al}(\mathrm{OH})_{3}$ должна происходить диффузия ионов $\mathrm{A}^{3+}$ или $\left[\mathrm{Al}\left(\mathrm{H}_{2} \mathrm{O}\right)_{2}(\mathrm{OH})_{4}\right]^{-}$с образованием обогащенного кремнеземом алюмосиликата. Относительно небольшое содержание ионов алюминия в слое кремнезема заметно понижает растворимость такого слоя. Этим эффектом можно объяснить осаждение $\mathrm{SiO}_{2}$ из ненасыщенного раствора. Основной реакционноспособной разновидностью являются

${ }_{55}^{54}$ См. сноску 53.

${ }^{55}$ Hingston F.J., Raupach M. The reaction between monosilicic acid and aluminum hydroxide. I: Kinetics of adsorption of monosilicic acid by aluminum hydroxide. Austr. J. Soil Res. 1967. № 5. P. 295-309. DOI: https://doi.org/10.1071/SR9670295. 
ионы $\mathrm{SiO}(\mathrm{OH})_{3}^{-}$. Для реакции с мономером $\mathrm{Si}(\mathrm{OH})_{4}$ требуется присутствие ионов $\mathrm{A}^{3+}$ или многоосновных ионов алюминия ${ }^{56}$.

Учитывая указанные выше процессы, подчеркиваем, что недостатком жидкого АКФК является способность к необратимому гелеобразованию при хранении и потере коагулирующих свойств.

Более перспективным является использование кремнийсодержащих коагулянтов в виде порошковой смеси силиката натрия и сульфата алюминия, что значительно упрощает технологию применения и позволяет увеличить срок хранения рабочих растворов ${ }^{57}$.

К таким порошковым реагентам относятся коагулянты АКФК и ФКФК, разработанные авторами ${ }^{58,59}$, коагулирующие свойства которых были изучены в ходе выполнения работы.

\section{2. Методики и объекты исследований}

В работе были использованы известные стандартные методы исследований и анализа. С использованием методов потенциометрии, турбидиметрии, $\mathrm{pH}$-метрии, спектрофотомерии были получены достоверные и воспроизводимые результаты.

Количественное определение эффективности использования неорганических коагулянтов для очистки природных вод осуществлялось по общим показателям качества воды. Все анализы проводились в соответствии со стандартными методиками.

Водородный показатель $(\mathrm{pH})$ измеряли с помощью иономера НI5222 и в соответствии с методикой, описанной в источнике ${ }^{60}$. Иономер HI-5222 - это профессиональный настольный прибор с цветным графическим ЖК-дисплеем для измерения $\mathrm{pH}$ (с калибровочной проверкой), окислительно-восстановительного потенциала с возможностью использования ионоселективных электродов и измерения температуры. Для калибровки использовались коммерчески доступные сертифицированные стандартные образцы буферных растворов сравнения.

Титрование коагулянтов-флокулянтов осуществляли с использованием указанного иономера, совмещенного с автоматическим потенциометрическим титратором НІ-931.

${ }^{56}$ См. сноску 53.

57 Литвинов А.И. Интенсификация технологии приготовления и применения активированной кремниевой кислоты при очистке южных рек : автореф. дисс. ... канд. техн. наук. Вологда, 2005. 23 с.

${ }^{58}$ См. сноску 4.

${ }^{59}$ См. сноску 6.

${ }^{60}$ Brown P.L., Sylva R.N., Ellis J., Batley G.E. The hydrolysis of metal ions. Part 8. Aluminium (III). J. Chem. Soc., Dalton Trans., 1967-1970. 
Мутность и цветность природной воды определяли по величине оптической плотности на фотоколориметре КФК-2 при $\mathrm{X}=540$ нм и 400 нм соответственно в кювете на 50 мм по методике, описанной в источнике $^{61}$. Цветность определяли в пробах очищенной воды после фильтрования через бумажный фильтр «Синяя лента».

Содержание остаточного алюминия определяли спектрофотометрическим методом по стандартной методике, описанной в источнике ${ }^{62}$. Метод основан на способности алюминия образовывать с алюминоном лак оранжево-красного цвета, представляющий комплексное соединение. Реакция осуществляется в слабокислой среде при $\mathrm{pH} 4,5$ в присутствии сульфата аммония в качестве стабилизатора окраски лака. У полученного раствора измеряется поглощение света при длине волны $525 \div 540$ нм. Предел обнаружения алюминия составляет 0,02 мг/л при объеме пробы $25 \mathrm{~cm}^{3}$ Диапазон измеряемых

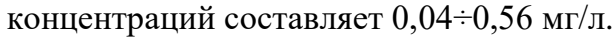

Содержание железа определяли по ГОСТу ${ }^{63}$. Метод основан на образовании в слабокислой среде окрашенного в красный цвет комплексного соединения ионов трехвалентного железа с сульфосалициловой кислотой. У полученного раствора измеряется поглощение света при длине волны 490 $\div 500$ нм. В щелочной среде $(\mathrm{pH}=8 \div 11,5)$ сульфосалициловая кислота реагирует с ионами трех- и двухвалентного железа, образуя комплекс желтого цвета, концентрацию которого определяют по поглощению света при длине волны $400 \div 420$ нм. Содержание двухвалентного железа находят по разности. Чувствительность метода составляет 0,05 мг/л Fe.

Поскольку коагуляционная очистка воды на водоочистных станциях осуществляется обычно по двухступенчатой схеме (коагуляция с отстаиванием и доочистка фильтрованием), коагуляцию осуществляли методом пробного коагулирования. Методика пробного коагулирования позволяет осуществить выбор коагулянта или флокулянта, определить его оптимальную дозу и эффективность применения для очистки исследуемой воды. Сущность метода пробного коагулирования заключается в обработке сточной воды реагентами в цилиндрах или стаканах при определенном стандартном режиме смешения и хлопьеобразования либо в условиях,

${ }^{61}$ ГОСТ Р 57164-2016, Вода питьевая. Методы определения запаха, вкуса и мутности. Дата издания: 31.10.2016.

${ }^{62}$ ГОСТ 18165-89, Вода питьевая. Метод определения массовой концентрации алюминия. Дата введения: 01.01.1991.

${ }^{63}$ ГОСТ 4011-72. Вода питьевая. Методы измерения массовой концентрации общего железа (с Изменениями № 1, 2). Дата введения: 01.01.1974. 
имитирующих коагуляционную очистку на существующих очистных сооружениях.

Смешение обычно осуществляется механической мешалкой, сначала быстро для равномерного распределения реагента в воде, затем медленно для создания крупных, быстро оседающих хлопьев скоагулированных загрязнений. Для этой цели применяется специальная установка пробного коагулирования «Капля», позволяющая обрабатывать одновременно 6 проб сточной воды и осуществлять перемешивание механическими мешалками с регулируемым числом оборотов в интервале от 10 до 200 об./мин ${ }^{64,65}$.

Смешение осуществляли в течение одной минуты при среднем градиенте скорости $\mathrm{G}=500 \mathrm{c}^{-1}$, хлопьеобразование в течение 5 мин при $\mathrm{G}=50 \mathrm{c}^{-1}$. Отстаивание осуществляли в течение 5 мин для выделения загрязнений с гидравлической крупностью более $0,03 \mathrm{mM} / \mathrm{c}$. Известно ${ }^{66}$, что интенсивность смешения реагентов с водой характеризуется градиентом скорости G, которые определяются из такого выражения:

$$
G=\sqrt{\frac{E}{\eta T V}},
$$

где $\mathrm{E}$ - энергия, затрачиваемая на смешение, Дж; $\eta$ - динамическая вязкость воды, Па с; Т - продолжительность смешения, с; V - объем воды в смесителе, м $^{3}$.

Для коагуляционной очистки воды в лабораторных условиях использовали $0,1 \%$ растворы коагулянтов в дистиллированной воде. Эксперименты проводили на реальной речной воде с различной исходной цветностью.

\section{1. Характеристика исследованных коагулянтов}

В работе применялись коагулянт АКФК, представляющий алюмокремниевый флокулянт-коагулянт формулы $4.4 \mathrm{Na}_{2} \mathrm{O} \cdot \mathrm{Al}_{2} \mathrm{O}_{3} \cdot 5.1 \mathrm{SiO}_{2} \cdot 6.6 \mathrm{SO}_{3} \cdot 4 \mathrm{H}_{2} \mathrm{O}$ с молекулярной массой $1281,6(\mathrm{TУ}$ 26351-0013578-61-08) и железо-кремниевый флокулянт-коагулянт ФКФК на основе железа сернокислого закисного формулы $10 \mathrm{Na}_{2} \mathrm{O} \cdot \mathrm{FeO} \cdot 5.2 \mathrm{SiO}_{2} \cdot 2 \mathrm{SO}_{3} \cdot 8 \mathrm{H}_{2} \mathrm{O}$ с молекулярной массой 1308,31 . Характеристики испытанных коагулянтов представлены в табл. 1. 
Таблица 1

Характеристики исследованных реагентов

\begin{tabular}{|c|c|c|c|}
\hline Коагулянт & $\begin{array}{c}\text { Содержание } \\
\text { основного вещества } \\
\text { по оксиду, \% }\end{array}$ & $\begin{array}{c}\text { Содержание } \\
\text { кремния } \\
\text { по оксиду, \% }\end{array}$ & $\begin{array}{c}\text { рН 0,1\% раствора } \\
\text { (по оксиду Al } \\
\text { или Fe) }\end{array}$ \\
\hline АКФК & 6,04 & 18,2 & 1,97 \\
\hline $\begin{array}{c}\text { Сульфат } \\
\text { алюминия }\end{array}$ & 15,3 & - & 2,7 \\
\hline ФКФК & 3,72 & 16,1 & 2,26 \\
\hline $\begin{array}{c}\text { Железный } \\
\text { купорос }\end{array}$ & 25,8 & - & 2,77 \\
\hline
\end{tabular}

Рабочий раствор коагулянта готовили растворением его навески, взвешенной на аналитических весах, в дистиллированной воде до концентрации 1\%. Дозировку реагента рассчитывали по активному веществу. В расчетах концентрации и дозировки коагулянта и флокулянта не учитывалась влажность, так как реагенты хранились в сухом месте в герметично закрытых емкостях.

При приготовлении рабочих растворов коагулянтов было установлено, что в воде коагулянты растворяются не полностью. Нерастворимая часть быстро оседает, и растворы коагулянтов становятся прозрачным по внешнему виду и не изменяются при хранении.

\section{2. Титрование флокулянтов-коагулянтов}

Кривые потенциометрического титрования, которые представлены на рис. 4 и 5, были сняты для характеристики свойств водных растворов коагулянтов.

Как следует из рис. 4, на кривых потенциометрического титрования композиционных коагулянтов, как и исходных сернокислых солей алюминия и железа, имеется характерный перегиб, соответствующий образованию гидроксидов алюминия или железа. Эквивалентная точка образования гидроксида алюминия составляет 6,8-7,0 для алюмосодержащих коагулянтов. Образования гидроксида железа происходит в диапазоне $\mathrm{pH}$ 9,6-9,8 для железосодержащих коагулянтов. Второй характерный перегиб, который особенно четко виден на кривой потенциометрического титрования железосодержащих коагулянтов с точкой эквивалентности в кислой области при $\mathrm{pH} 4,5$, соответствует, очевидно, образованию силиката натрия из кремниевой кислоты. Также нельзя исключать возможности формирования в этой точке силикатов алюминия или железа, поскольку в этих условиях еще 
присутствуют их простые катионные формы в соответствии с данными, приведенными на рис. 4 и 5.

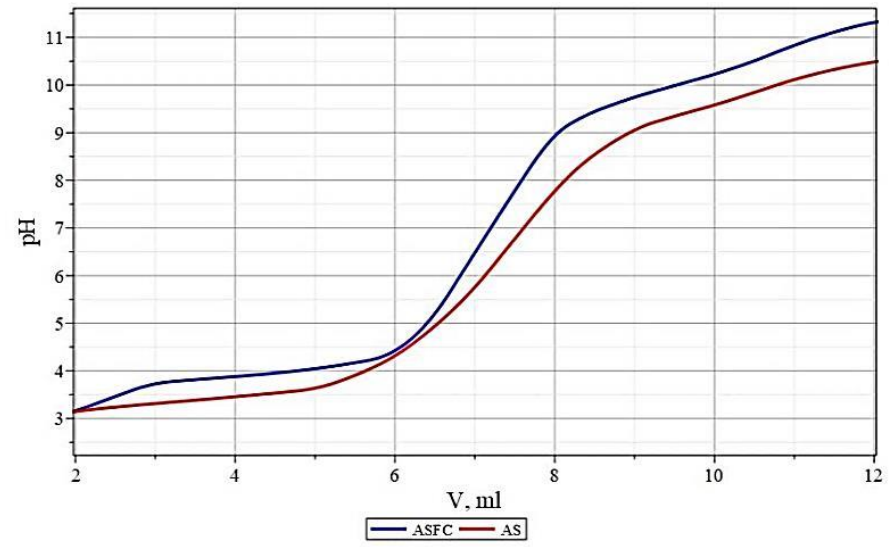

Рис. 4. Кривые потенциометрического титрования $0,1 \%$ растворов коагулянтов 0,1 Н раствором $\mathrm{NaOH}$ (ASFC - флокулянт-коагулянт АКФК, AS - сульфат алюминия)

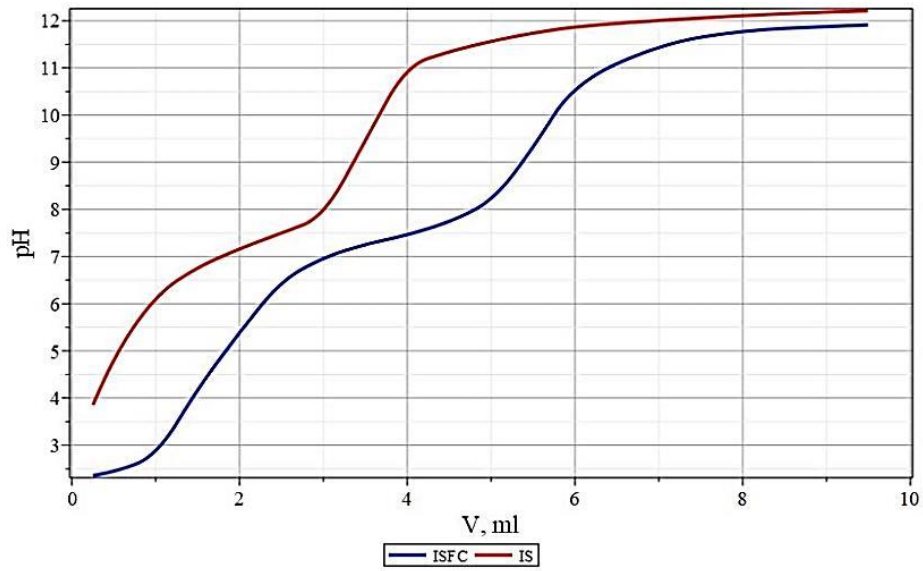

Рис. 5. Кривые потенциометрического титрования 0,1\% растворов коагулянтов 0,1 Н раствором $\mathrm{NaOH}$ (ISFC - флокулянт-коагулянт ЖКФК, AS - сульфат железа (II)) 
Титрование раствора соли алюминия с основанием обычно дает кривую, подобную кривой на рис. 4. На этой кривой можно выделить четыре области в зависимости от количества добавленного основания. В первой области, в начале кривой, основание нейтрализует свободную кислоту, образующуюся при самопроизвольном гидролизе, что приводит к быстрому повышению $\mathrm{pH}$. Выше приблизительно $\mathrm{pH} 4$ образуются гидролизованные частицы, а также существует расширенная часть кривой, где $\mathrm{pH}$ увеличивается медленно, поскольку добавленное основание расходуется для гидролиза соли алюминия. В этой области могут образовываться большие количества полимерных частиц и гидроксокомплексов, которые становятся преобладающими в растворе веществами при большом количестве добавленной щелочи. При титровании добавление основания может приводить к различным эффектам в зависимости от условий смешивания. Например, оно может приводить к локальному перенасыщению и осаждению аморфного гидроксида или избыточному образованию иона $\left[\mathrm{Al}\left(\mathrm{H}_{2} \mathrm{O}\right)_{2}(\mathrm{OH})_{4}\right]^{-}$. Эти условия могут также способствовать формированию полимера $\left[\mathrm{Al}_{13}(\mathrm{OH})_{32}\right]^{7+}$, хотя тут не существует четкой однозначности.

Дальнейшее увеличение количества добавленной щелочи дает третью область, в которой на кривой появляется небольшое плечо после резкого повышения $\mathrm{pH}$. В этой области происходит перенасыщение раствора относительно аморфного $\mathrm{Al}(\mathrm{OH})_{3}$, а также его быстрое осаждение. Это плечо усиливается в хлоридных растворах и ослабевает в присутствии сильно заряженных анионов, таких как сульфат, которые могут способствовать осаждению гидроксида ${ }^{67}$. В случае АКФК уменьшению и сдвигу этого плеча способствует не только наличие сульфат ионов $\mathrm{SO}_{4}^{2-}$, но и наличие силикат-ионов $\mathrm{SiO}_{3}^{2-}$, которые входят в его состав.

В четвертой области добавленное основание уменьшает положительный поверхностный заряд частиц коллоидного гидроксида, из-за чего образуются видимые осадки. Дальнейшее добавление основания дает быстрое увеличение $\mathrm{pH}$ за счет растворения гидроксида алюминия и образования алюминат-ионов $\left[\mathrm{Al}\left(\mathrm{H}_{2} \mathrm{O}\right)_{2}(\mathrm{OH})_{4}\right]^{-}$и $\left[\mathrm{Al}(\mathrm{OH})_{6}\right]^{3-}$.

Для ЖКФК наблюдается похожая ситуация. Отличие ЖКФК от АКФК заключается в сдвиге перегиба на кривых титрования в кислую область. Однако третья область на этой кривой проявляется более

${ }^{67}$ De Hek H., Stol R.J., De Bruyn P.L Hydrolysis-precipitation studies of aluminum (III) solutions. 3. The role of the sulfate ion. Journal of Colloid and Interface Science. 1978. V. 64. Issue 1. P. 72-89. ISSN 0021-9797. DOI: https://doi.org/10.1016/00219797(78)90336-3. 
четко, чем в случае с АКФК. Такое их поведение связано с тем, что сульфат-ионы $\mathrm{SO}_{4}^{2-}$ и силикат-ионы $\mathrm{SiO}_{3}^{2-}$, которые входят в его состав, оказывают меньшее воздействие на формирующийся гидроксид железа (II) $\mathrm{Fe}(\mathrm{OH})_{2}$.

Образующийся гидроксид железа (II) $\mathrm{Fe}(\mathrm{OH})_{2}$ относительно хорошо растворяется в воде, поэтому он находится в диссоциированном состоянии, как следствие, в воде не происходит хлопьеобразования. Следовательно, для наиболее полной коагуляции при использовании сульфата железа образующийся гидроксид железа (II) необходимо перевести в гидроксид железа (III). Последнее может происходить при обработке очищаемой воды, насыщенной кислородом:

$$
4 \mathrm{Fe}(\mathrm{OH})_{2}+\mathrm{O}_{2}+2 \mathrm{H}_{2} \mathrm{O}=4 \mathrm{Fe}(\mathrm{OH})_{3} .
$$

Установлено, что хлопья гидроксида железа наиболее эффективно образуются при рН 5-7, а лучше всего при рН 6,1-6,5. В дополнение к этому процессу в щелочной среде происходит дополнительное окисление гидроксида железа (II) растворенным в воде кислородом с образованием гидроксида железа (III) $\mathrm{Fe}(\mathrm{OH})_{3}$.

$$
\begin{gathered}
\mathrm{Fe}(\mathrm{OH})_{2}+\mathrm{H}_{2} \mathrm{O} \rightarrow \mathrm{Fe}(\mathrm{OH})_{3}+H^{+}+e^{-} ; \\
\varphi=0.271-0.0591 \cdot p H .
\end{gathered}
$$

Этот процесс протекает наиболее легко в щелочной области и способствует дополнительному расходу щелочи. В четвертой области добавление основания также уменьшает положительный поверхностный заряд частиц коллоидного гидроксида железа, образуются осадки, активно взаимодействующие с флокулянтом, то есть коллоидным оксидом кремния.

\section{3. Изменение буферной емкости растворов коагулянтов}

При потенциометрическом титровании растворов коагулянтов было обнаружено, что они ведут себя как буферные растворы, то есть растворы с определенной устойчивой концентрацией водородных ионов. Изучение зависимости буферной емкости растворов коагулянтов от их $\mathrm{pH}$ позволяет получить более детальную информацию о строении веществ, образующихся в процессах коагуляции. У растворов коагулянтов, как и у буферных растворов, $\mathrm{pH}$ мало изменяется при прибавлении к ним небольших количеств сильного основания или сильной кислоты. Приготовленные растворы сохраняют определенное значение $\mathrm{pH}$ только до определенного 
количества добавляемой кислоты или основания, что связано с изменением концентраций его компонентов.

Способность буферного раствора сохранять свой $\mathrm{pH}$ определяется его буферной емкостью, то есть количеством сильной кислоты или щелочи, которые необходимо прибавить к определенному объему буферного раствора, чтобы его рН остался постоянным или изменился в пределах допускаемой величины. Буферная емкость тем выше, чем больше концентрация его компонентов. Буферная емкость является количественной мерой устойчивости к изменению $\mathrm{pH}$ раствора, содержащего буферный агент, по отношению к изменению концентрации кислоты или щелочи. Его можно определить таким образом $^{68,69}$

$$
\beta=\frac{d C_{b}}{d(p H)}
$$

где $d C_{b}$ - бесконечно малое количество добавленного раствора щелочи. Рассматривая зарядовую симметрию касательно катионов и анионов, для кислотного титрования имеем аналогичное уравнение:

$$
\beta=\frac{d C_{a}}{d(p H)},
$$

где $d C_{a}$ - бесконечно малое количество добавленного раствора кислоты; $d(p H)$ - бесконечно малое изменение $\mathrm{pH}$, соответствующее данному количеству добавленного раствора титранта. Поскольку коагулянты гидролизуются под действием основания, то их можно рассматривать как слабые кислоты. При любом определении буферная емкость для слабой кислоты НА с константой диссоциации $K_{a}$ может быть выражена таким образом ${ }^{70,71}$ :

$$
\beta=\ln 10 \cdot\left(a_{H^{+}}+\frac{T_{H A} \cdot K_{a} \cdot a_{H^{+}}}{\left(K_{a}+a_{H^{+}}\right)^{2}}+\frac{K_{w}}{a_{H^{+}}}\right),
$$

где $a_{H^{+}}-$активность ионов водорода, $T_{H A}-$ общая концентрация добавленной кислоты, $K_{w}$ - константа равновесия ионизации воды (ионное произведение воды), равная $p K_{w}=14$. Необходимо обратить

${ }^{68}$ Skoog D.A., West D.M., Holler F.J., Crouch S.R. Fundamentals of Analytical Chemistry. 9th ed. Brooks/Cole. 2014. 226 p. ISBN 978-0-495-55828-6.

${ }^{69}$ Urbansky E.T., Schock M.R. Understanding, Deriving and Computing Buffer Capacity. Journal of Chemical Education. 2000. № 77 (12). P. 1640-1644. DOI: 10.1021/ed077p1640.

70 Butler J.N. Ionic Equilibrium: Solubility and $\mathrm{pH}$ calculations. Wiley. 1998. P. 133-136. ISBN 978-0-471-58526-8.

${ }^{71}$ Hulanicki A. Reactions of acids and bases in analytical chemistry / translated by M.R. Masson. Horwood, 1987. ISBN 978-0-85312-330-9. 
внимание на то, что в растворе ионы $\mathrm{H}^{+}$существуют в виде ионов гидроксония $\mathrm{H}_{3} \mathrm{O}^{+}$. Дальнейшая гидратация иона гидроксония имеет незначительное влияние на равновесие диссоциации, за исключением очень высокой концентрации кислоты.

Это уравнение показывает, что существует три области повышенной буферной емкости. В центральной области кривой (5) доминирующим является второй член, поэтому выражение (5) принимает такой вид:

$$
\beta=\ln 10 \cdot \frac{T_{H A} \cdot K_{a} \cdot a_{H^{+}}}{\left(K_{a}+a_{H^{+}}\right)^{2}} .
$$

Буферная емкость возрастает до локального максимума при $p H=$ $p K_{a}$. Для коагулянтов высота этого пика зависит от таких факторов, как концентрация, механизм гидролиза и величины $p K_{a}$. Буферная емкость незначительна, когда концентрация [НА] буферного агента очень мала, и увеличивается с увеличением концентрации буферного агента $^{72}$. Некоторые авторы показывают только эту область на графиках буферной емкости ${ }^{73}$.

Буферная емкость падает при отклонении от максимального значения при $p H=p K_{a}$.

Для сильнокислых растворов в левой часть кривой доминирует первый член в уравнении (14), а буферная емкость возрастает экспоненциально с уменьшением $\mathrm{pH}$ :

$$
\beta \approx 10^{-p H} .
$$

Подобная ситуация объясняется тем, что второе и третье слагаемые становятся незначительными при очень низких значениях $\mathrm{pH}$. Это состояние не зависит от наличия или отсутствия буферного агента и является естественным свойством водородного показателя $\mathrm{pH}$. В случае сильнощелочных растворов преобладает правая часть кривой. В данных условиях она определяется третьим членом и доминирует в уравнении (14), а буферная емкость в этих условиях возрастает экспоненциально с ростом $\mathrm{pH}$ :

$$
\beta \approx 10^{p H-K_{w}} .
$$

Уравнение (17) является следствием того, что первое и второе слагаемые становятся незначительными при очень высоком $\mathrm{pH}$. Это

72 Urbansky E.T., Schock M.R. Understanding, Deriving and Computing Buffer Capacity. Journal of Chemical Education. 2000. № 77 (12). P. 1640-1644. DOI: $10.1021 /$ ed077p1640.

${ }^{73}$ Skoog D.A., West D.M., Holler F.J., Crouch S.R. Fundamentals of Analytical Chemistry. 9th ed. Brooks/Cole. 2014. 226 p. ISBN 978-0-495-55828-6. 
состояние также не зависит от наличия или отсутствия буферного агента.

Кривые изменения буферной емкости растворов коагулянтов представлены на рис. 6 и 7. Рассчитанные на их основе параметры буферной емкости представлены в табл. 2.

Таблица 2

Положение максимумов на кривых изменения буферной емкости растворов коагулянтов

\begin{tabular}{|c|c|c|c|c|c|c|c|c|}
\hline \multirow{2}{*}{ Коагулянт } & \multicolumn{6}{|c|}{ Величина рН, соответствующая максимуму } \\
\cline { 2 - 10 } & \multicolumn{2}{|c|}{$\mathbf{2}$} & \multicolumn{2}{|c|}{$\mathbf{2}$} & \multicolumn{2}{|c|}{$\mathbf{3}$} & \multicolumn{2}{|c|}{$\mathbf{4}$} \\
\cline { 2 - 9 } & $\mathbf{p H}_{\max }$ & $\boldsymbol{\beta}$ & $\mathbf{p H}_{\max }$ & $\boldsymbol{\beta}$ & $\mathbf{p H}_{\max }$ & $\boldsymbol{\beta}$ & $\mathbf{p H}_{\max }$ & $\boldsymbol{\beta}$ \\
\hline АКФК & 2,97 & 4,22 & 3,83 & 7,77 & 9,99 & 2,11 & $>11,5$ & $>6,7$ \\
\hline $\begin{array}{c}\text { Сульфат } \\
\text { алюминия }\end{array}$ & 2,73 & 6,3 & 3,35 & 7,00 & 9,44 & 2,14 & $>10,7$ & $>5,8$ \\
\hline ФКФК & $<2,5$ & $>2,5$ & - & - & 7,34 & 2,41 & $>11,8$ & $>9,5$ \\
\hline $\begin{array}{c}\text { Железный } \\
\text { купорос }\end{array}$ & - & - & - & - & 7,47 & 1,49 & $>12$ & $>9,5$ \\
\hline
\end{tabular}

При титровании растворов коагулянтов проводилось измерение не только $\mathrm{pH}$ и буферной емкости, но и изменения мутности раствора методом турбидиметрии для контроля процесса образования твердой фазы.

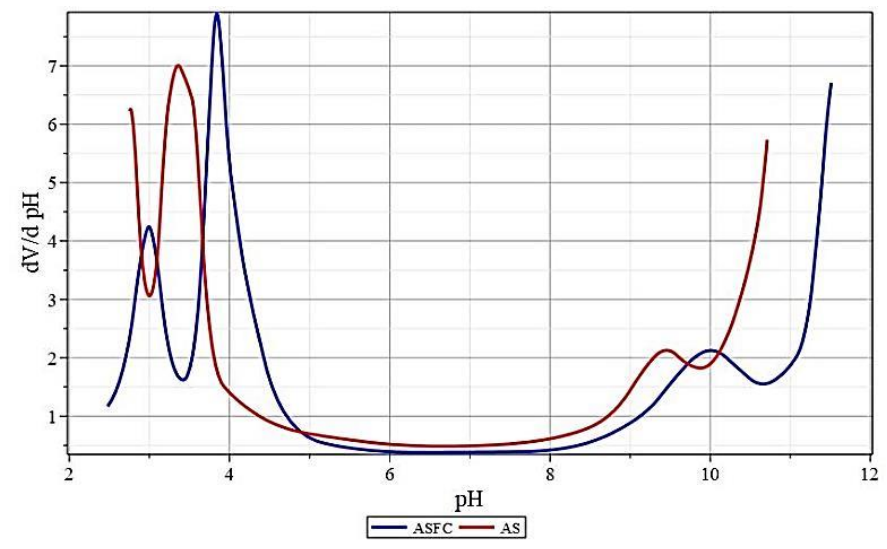

Рис. 6. Кривые изменения буферной емкости растворов коагулянтов (ASFC - флокулянт-коагулянт AКФК, AS - сульфат алюминия) 


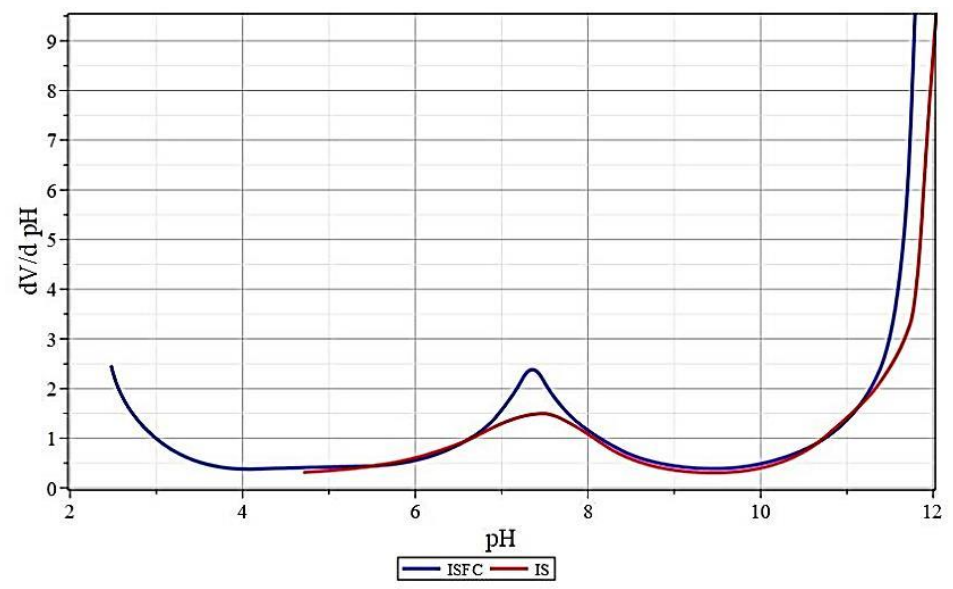

Рис. 7. Кривые изменения буферной емкости растворов коагулянтов (ISFC - флокулянт-коагулянт ЖКФК, IS - сульфат железа (II))

\section{4. Турбидиметрические исследования коагулянтов-флокулянтов}

Для характеристики свойств водных растворов коагулянтов были сняты кривые турбидиметрического титрования, которые представлены на рис. 8.

В турбидиметрическом анализе используется явление рассеяния света твердыми частицами, находящимися в растворе во взвешенном состоянии $^{74}$.

Пробу освещают потоком света с интенсивностью $I_{0}$, а затем, как в молекулярной абсорбционной спектроскопии, измеряют интенсивность прошедшего излучения $I$ или определяют интенсивность излучения, рассеянного под определенным углом (например, $I_{90}$ при $90^{\circ}$ ). С ростом числа частиц суспензии отношение $I / I_{0}$ уменьшается, а отношения вида $I_{90} / I_{0}$ увеличиваются, во всяком случае до умеренных концентраций. Для очень разбавленных суспензий измерение под углом гораздо чувствительнее, чем измерения, когда источник и приемник излучения находятся на одной линии, поскольку при этом можно наблюдать слабый рассеянный свет на темном фоне.

Интенсивность падающего светового потока ослабляется в результате его рассеяния дисперсной системой. Если принять рассеянный свет за фиктивно поглощенный, то можно получить

74 Фролов Ю.Г. Курс коллоидной химии. Поверхностные явления и дисперсные системы. М.: Химия, 1988. - 464 с., ISBN 5-7245-0244-5 
простое соотношение, аналогичное закону Ламберта-Бугера-Бэра для поглощения света молекулярными растворами. Ослабление интенсивности света $d I$ пропорционально интенсивности падающего света $I$, проходящего через слой исследуемой системы толщиной $d x$, измеряется таким образом:

$$
\frac{d I}{d x}=\tau I
$$

где $\tau-$ коэффициент пропорциональности, характеризующий способность системы рассеивать свет, его называют мутностью. Для турбидиметрических измерений можно использовать любой фотометр или спектрофотометр. Если растворитель и рассеивающие частицы бесцветны, максимальная чувствительность достигается при использовании излучения голубой или ближней ультрафиолетовой области. Для окрашенных систем оптимальную длину волны необходимо подбирать экспериментально. В результате интегрирования уравнения (18) в пределах от $I_{0}$ до $I$ и, соответственно от $x=0$ до $l$ - толщины слоя системы, получим такое выражение:

$$
D_{\lambda}=\ln \frac{I}{I_{0}}=-\tau l
$$

где $\tau$ - константа, зависящая от геометрии и свойств исследуемой системы.

Из уравнения (19) следует, что мутность $D_{\lambda}$ представляет собой логарифмическую зависимость отношения интенсивностей рассеянного и падающего света, отнесенную к единице длины луча света, проходящего через образец. Это отношение, в соответствии с законом Рэлея, равно:

$$
D_{\lambda}=\ln \frac{I}{I_{0}}=-l \frac{c v d^{3}}{d^{4}+\alpha \lambda^{4}}(\cos \theta)^{2},
$$

где $d$ - диаметр частиц; $v$ - счетная концентрация дисперсных частиц в растворе; $\alpha$ - константа, зависящая от природы дисперсной системы; c - константа, включающая постоянные параметры в уравнении Рэлея; $\lambda$ - длина волны света, падающего на ячейку; $\theta$ - угол между направлением рассеяния света и направлением потока падающего света.

Формула Рэлея для интенсивности света, рассеянного единицей объема дисперсной системы со сферическими частицами, справедлива для частиц, которые значительно меньше длины волны падающего света. Обычно считается, что размер частиц должен быть не более $0,1 \cdot \lambda$. Поэтому в экспериментах обычно используется излучение с длиной волны $\lambda=540$ нм. 
Кривые турбидиметрического титрования растворов АКФК и сульфата алюминия раствором щелочи представлены на рис. 8. Они показывают, что для обоих коагулянтов продукты гидролиза имеют примерно близкую максимальную оптическую плотность $\mathrm{D}_{540}$, то есть компонентный состав АКФК не оказывает существенного влияния на оптическую плотность конечных продуктов гидролиза коагулянта.

Однако наблюдаются определенные различия в их поведении. Так, для сульфата алюминия максимум на этой кривой достигается при $\mathrm{pH} \approx 10,5$. Кроме того, оптическая плотность почти линейно растет от $\mathrm{pH}=4$, хотя на общем фоне эти изменения носят незначительный характер. Они могут быть связаны с ростом размеров частиц гидроксида алюминия и одновременным уменьшением их частичной концентрации в единице объема исследуемого раствора. В этом плане кривые турбидиметрического титрования раствора АКФК имеют другой вид и характеризуются двумя подобными участками: левый в диапазоне 4,5 $\leq p H \leq 6,5$ и правый в диапазоне $6,5 \leq p H \leq 10$. Можно предположить, что эти отклонения и подобное поведение обусловлены присутствием второго компонента АКФК, а именно активной кремневой кислоты. Судя по внешнему виду полученных зависимостей, можем предположить, что более детальное описание этих зависимостей можно получить при построении их производных по pН. График функции $\frac{d D_{540}}{d p H}=f(p H)$ для АКФК и сульфата алюминия представлен на рис. 9.

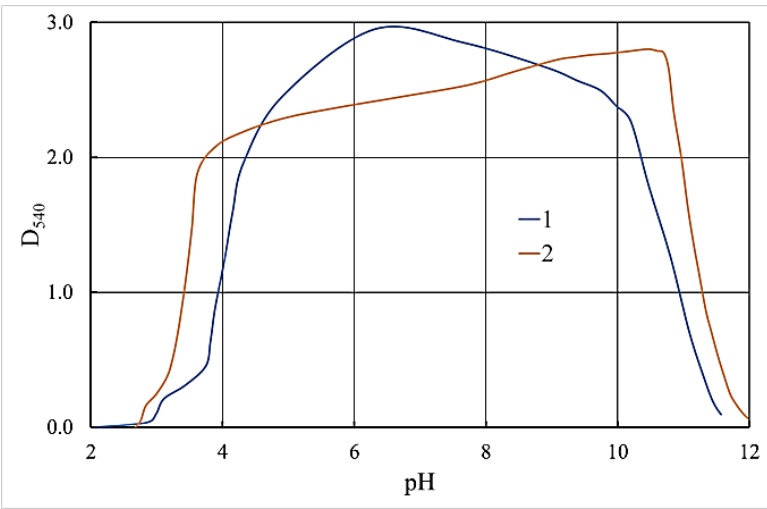

Рис. 8. Кривые турбидиметрического титрования $0,1 \%$ растворов коагулянтов 0,1 Н $\mathrm{NaOH} \mathrm{(1} \mathrm{-} \mathrm{АКФК;} 2$ - сульфат алюминия;

D540 - оптическая плотность раствора при использовании излучения с длиной волны $\lambda=540$ нм) 


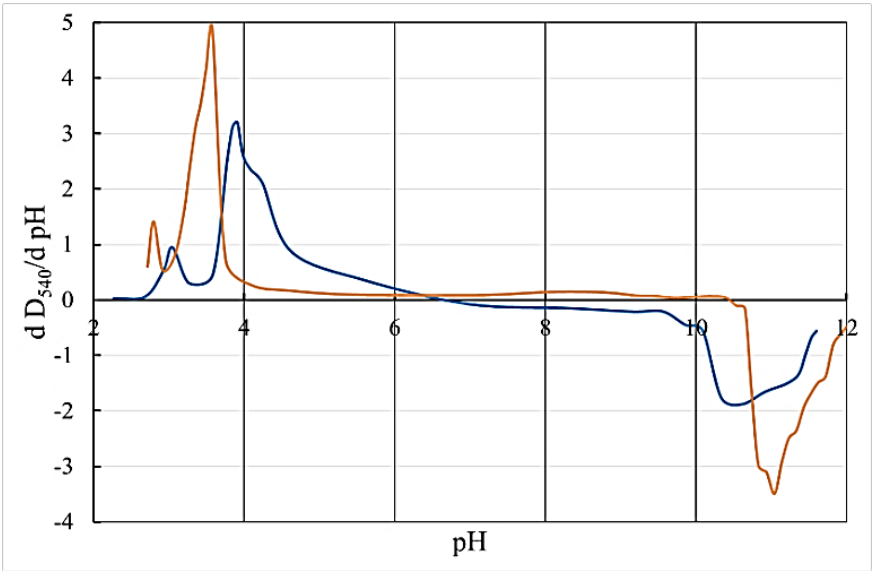

Рис. 9. Производные $\frac{d D_{540}}{d p H}$ от кривых турбидиметрического титрования

0,1\% растворов коагулянтов (титрант 0.1 Н NaOH; 1 - АКФК;

2 - сульфат алюминия; D540 - оптическая плотность раствора при использовании излучения с длиной волны $\lambda=540$ нм)

Представленные на рис. 9 зависимости очень похожи на зависимости буферной емкости от $\mathrm{pH}$, хотя экстремумы на них не совпадают. Положение экстремумов на данных зависимостях представлено в табл. 3. Сравнивая эти данные с данными табл. 2, можем увидеть, что в данном случае положение экстремумов сдвинуто в сторону нейтральных значений $\mathrm{pH}$. Этот эффект указывает на отсутствие прямой связи между помутнением растворов и протекающими в них гидролитическими реакциями. Кроме того, следует обратить снимание на то, что экстремумы на представленных зависимостях более расширены для АКФК по сравнению с сульфатом алюминия. Можно предположить, что данный эффект также связан с влиянием активной кремневой кислоты и объясняется гетерокоагуляционным характером осаждения гидроксида алюминия в ее присутствии.

Однако есть и существенная разницы между характерами седиментационныъ турбодиметрических кривых. Рис. 9 показывает, что диапазон $\mathrm{pH}$ осаждения сульфата алюминия оказался несколько шире, чем этот диапазон для АКФК. С каждой стороны он примерно на 0,5 единиц $\mathrm{pH}$ шире. 
Таблица 3

Положение особых точек на кривых турбидиметрического титрования для 0,1\% растворов коагулянтов (титрант $0.1 \mathrm{H} \mathrm{NaOH}$ )

\begin{tabular}{|c|c|c|c|c|c|c|}
\hline \multirow{2}{*}{ Коагулянт } & \multicolumn{2}{|c|}{$\mathbf{1}$} & \multicolumn{2}{|c|}{$\mathbf{2}$} & \multicolumn{2}{|c|}{$\mathbf{3}$} \\
\cline { 2 - 7 } & $\mathbf{p H}$ & $\frac{\boldsymbol{d} \boldsymbol{D}_{\mathbf{5 4 0}}}{\boldsymbol{d} \boldsymbol{p H}}$ & $\mathbf{p H}$ & $\frac{\boldsymbol{d} \boldsymbol{D}_{\mathbf{5 4 0}}}{\boldsymbol{d p H}}$ & $\mathbf{p H}$ & $\frac{\boldsymbol{d} \boldsymbol{D}_{\mathbf{5 4 0}}}{\boldsymbol{d} \boldsymbol{p H}}$ \\
\hline АКФК & 3,05 & 0,95 & 3,91 & 3,20 & 10,61 & $-1,88$ \\
\hline Сульфат алюминия & 2,79 & 1,41 & 3,57 & 4,88 & 11,04 & $-3,49$ \\
\hline
\end{tabular}

\section{5. Определение $\zeta$-потенциала и изоэлектрической точки для}

\section{гидроксида алюминия, полученного при гидролизе коагулянта}

Как уже отмечалось, процесс коагуляции сильно зависит от $\mathrm{pH}$ среды, в первую очередь он определяет заряд частиц суспензии, образующейся при коагуляции. В данном случае ионы $\mathrm{H}_{3} \mathrm{O}^{+}$и $\mathrm{OH}^{-}$ играют роль потенциалопределяющих ионов на межфазной поверхности гидроксид/водный раствор. Например, при $\mathrm{pH}<\mathrm{pH}_{\text {iep }}$ появление положительного заряда на частицах гидроксида алюминия обусловлено адсорбцией ионов водорода, поскольку в этой среде они являются потенциалопределяющими ионами ${ }^{75,76}$. На рис. 10 представлены результаты измерения электрокинетического

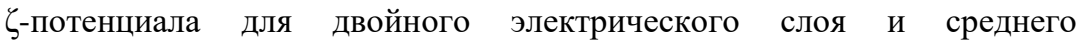
измеряемого размера частиц гидроксида алюминия при его образовании из соли алюминия в зависимости от $\mathrm{pH}$ среды. Эти данные были получены на приборе "The NanoPlus" фирмы "Micromeritics Instrument Corp." ${ }^{, 77}$.

Представленные на рис. 10 данные показывают, что при рН вблизи изоэлектрической точки происходит слипание первичных частиц гидроксида алюминия, что выражается в увеличении измеряемых размеров частиц в образующейся суспензии. При этом избыточная адсорбция одного из этих ионов определяет плотность и знак электрического заряда на поверхности частиц твердой фазы, что

${ }^{75}$ Кудрявцев П.Г., Кудрявцев Н.П., Фиговский О.Л. Растворимые соединения алюминия и нанокомпозитные материалы на их основе. Ч. II. Нанотехнологии в строительстве. 2018. Т. 10. № 2. C. 63-85. DOI: dx.doi.org/10.15828/2075-85452018-10-2-63-85.

76 Kudryavtsev P., Kudryavtsev N. Nanocomposite materials based on soluble aluminum compounds. Scientific Israel-Technological Advantages. 2017. Vol. 19. № 3. P. 40-76 ISSN: 1565-1534.

${ }^{77}$ NanoPlus. Zeta Potential and Nano Particle Analyzer. Micromeritics Instrument Corp. URL: http://www.particulatesystems.com/Repository/Files/NanoPlus_Brochure_ Final_v8.pdf. 
вызывает два эффекта. Первый эффект обеспечивает рост электростатического отталкивания, а второй приводит к понижению межфазного натяжения. Оба этих эффекта способствуют снижению энергии Гиббса, что приводит к протеканию процессов пептизации и разрушению образующегося осадка коагулята.

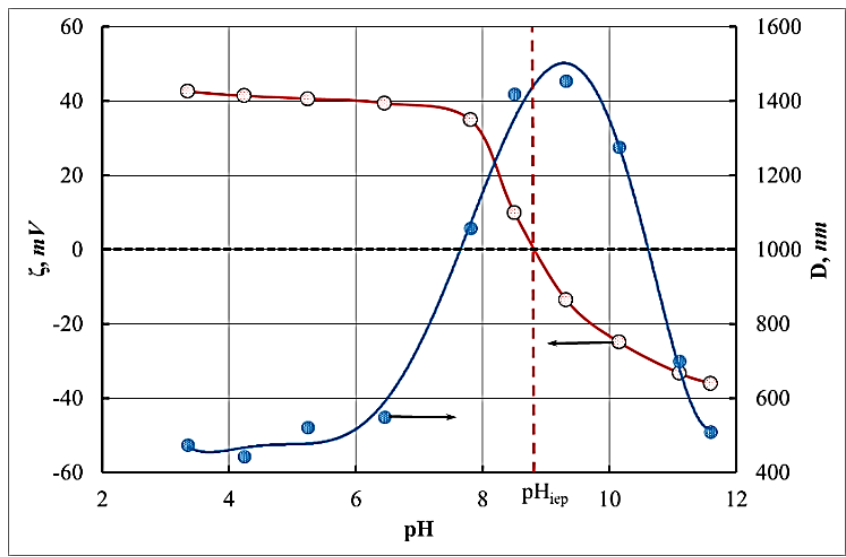

Рис. 10. Изменение величины электрокинетического ל-потенциала для двойного электрического слоя и среднего измеряемого размера частиц у гидроксида алюминия в зависимости от $\mathbf{p H}$ (рНіер - изоэлектрическая тока $(\mathrm{pHiep=8,87))}$

\section{6. Взаимодействие активной кремневой кислоты и продуктов гидролиза солей алюминия как компонентов композиционных флокулянтов-коагулянтов}

Проблема совместной коагуляции коллоидных дисперсий, состоящих из двух различных типов коллоидных частиц, имеет большое практическое значение и вызывает естественный интерес у многих исследователей ${ }^{78,79}$. В этом разделе мы рассмотрим влияние состояния индивидуальных компонентов композиционных флокулянтов-коагулянтов на скорость и характер взаимодействия активной кремневой кислоты и продуктов гидролиза солей алюминия.

${ }^{78}$ Harding R.D. Heterocoagulation in mixed dispersion-effect of particle size, size ratio, relative concentration and surface potential of colloidal components. Colloid and Interface Sci. 1972. V. 10. No. 2 P. 164-173.

${ }^{79}$ Kuo J.F., Yen T.F. Some aspects in predicting the point of zero charge of a composite oxide systems. Colloid and Interface Sci. 1988. V. 121. No. 1. P. 220-225. 
Как известно, устойчивость коллоидов зависит от природы дисперсной фазы, заряда и размера коллоидных частиц, $\mathrm{pH}$ и ионной силы раствора, температуры и других факторов ${ }^{80}$. Кроме того, при взаимодействии в растворе двух различных дисперсных фаз большое значение имеет соотношение размеров и масс дисперсных частиц ${ }^{81}$.

Один из важных параметров, определяющих стабильность золей, это заряд коллоидных частиц. Ионы гидроксония $\mathrm{H}_{3} \mathrm{O}^{+}$и гидроксила $\mathrm{OH}^{-}$являются потенциалом, определяющимся для коллоидных дисперсий оксидов кремния и алюминия, а также для других дисперсий оксидов и оксигидратов металлов. Известно, что кремнезоль при $\mathrm{pH}=8,0$ имеет ל-потенциал, равный $25 \mathrm{mB}, \mathrm{pH}=2,2$ соответствует точке нулевого заряда, при $\mathrm{pH}=1,0$ частицы приобретают небольшой положительный заряд. Алюмозоль при $\mathrm{pH}=3,6$ имеет $\zeta=+60$ мВ. При определенных концентрациях и размерах частиц коллоидный раствор оксида алюминия очень чувствителен к изменению $\mathrm{pH}$. При этом коллоидный раствор оксида кремния довольно устойчив в широком диапазоне $\mathrm{pH}$, поэтому было изучено влияние заряда частиц коллоидного раствора оксида кремния, то есть его $\mathrm{pH}$, на стабильность системы, содержащей смесь соответствующих коллоидных растворов. При этом параметры продуктов гидролиза солей алюминия поддерживались на постоянном уровне.

Зависимость времени жизни смешанной алюмосиликатной дисперсной системы от заряда $(\mathrm{pH})$ кремнезоля и их соотношения представлена на рис. 10. Очевидно, что максимальная разница в зарядах вызывает быструю коагуляцию в большом диапазоне составов смешанной системы (кривая 3). Стабильность смешанной системы повышается с уменьшением $\mathrm{pH}$ силикатной составляющей (кривые 1 и 2). Этот эффект объясняется уменьшением разницы в зарядах активной кремневой кислоты и продуктов гидролиза солей алюминия.

Однако в широком диапазоне $\mathrm{pH}$ положение точки минимума на графиках времени жизни смешанных алюмо-кремнезолей от соотношения компонентов меняется довольно значительно (рис. 12). Особенно значительное смещение минимума в сторону с малым содержанием алюминия в смешанной системе наблюдалось в щелочной области. Во всех случаях стабильность индивидуальных компонентов выше, чем смешанных систем.

${ }^{80}$ Фролов Ю.Г. Курс коллоидной химии. Поверхностные явления и дисперсные системы. Москва : Химия, 1988. 464 с. ISBN 5-7245-0244-5.

${ }^{81}$ Harding R.D. Heterocoagulation in mixed dispersion-effect of particle size, size ratio, relative concentration and surface potential of colloidal components. Colloid and Interface Sci. 1972. V. 10. No. 2. P. 164-173. 
Взаимодействие разноименно заряженных дисперсных систем существенно отличалось по скорости от других случаев (рис. 11, кривая 3), оно напоминало коагуляцию алюмозоля под действием щелочного агента, поэтому возникает вопрос о характере коагуляции. В этом случае возможны два механизма протекания этого процесса. Первый вариант этого механизма представляет собой гомокоагуляцию индивидуальной дисперсии под действием дополнительного электролита, вводимого в систему со вторым компонентом. Второй вариант - это гетерокоагуляция, то есть непосредственное взаимодействие частиц индивидуальных дисперсных систем.

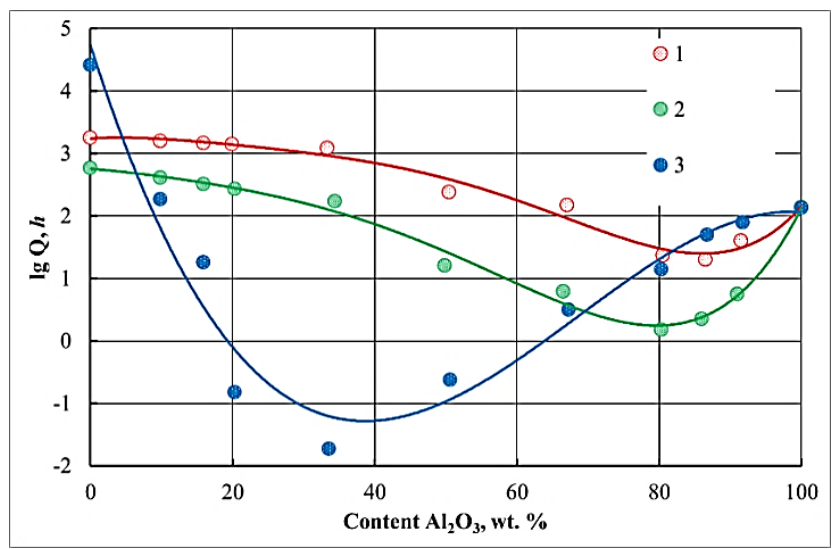

Рис. 11. Зависимость времени гелеобразования $(Q$, ч) для смеси кремнеи алюмозолей от соотношения компонентов и $\mathrm{pH}$ исходного кремнезоля (данные получены при таких значениях рН: 1-1,0; 2-2,8; 3-8,0)

Для решения этого вопроса был проведен такой эксперимент. Были подготовлены индивидуальные модельные дисперсные системы, смешивали активную кремневую кислоту с $\mathrm{pH}=8,0$ (3 мас.\% $\left.\mathrm{SiO}_{2}\right)$ и суспензию гидроксида алюминия с $\mathrm{pH}=3,6$ (3 мас.\% $\left.\mathrm{Al}_{2} \mathrm{O}_{3}\right)$ в соотношении 1:1. Для сравнения были созданы две такие системы, моделирующие процесс гомокоагуляции под воздействием электролитного фона:

- активная кремневая кислота $\left(\mathrm{pH}=8,0 ; 6\right.$ масс.\% $\left.\mathrm{SiO}_{2}\right)$, которую разбавляли водой с $\mathrm{pH}=3,6$ в соотношении $1: 1$;

- суспензия гидроксида алюминия $\left(\mathrm{pH}=3,6 ; 6\right.$ масс.\% $\left.\mathrm{Al}_{2} \mathrm{O}_{3}\right)$, которую разбавляли водой с $\mathrm{pH}=8,0$ в соотношении 1:1. 
Во всех случаях концентрация дисперсной фазы составляла $3 \%$. Время жизни смешанной алюмосиликатной системы равнялось $10 \div 20$ мин. Устойчивость индивидуальных модельных систем была значительно выше, что свидетельствует о преимущественном гетерокоагуляционном характере протекания процесса коагуляции в смешанной системе.

Этот вывод вызывал некоторые сомнения в случае значительного преобладания в системе $\mathrm{SiO}_{2}(\mathrm{pH}=8,0)$. В первый момент при смешении дисперсий в соотношениях $\mathrm{Al}_{2} \mathrm{O}_{3}: \mathrm{SiO}_{2}$ от 1:6 до 1:14 происходит местное гелирование, а через некоторый промежуток времени в смешанной системе наблюдается гелирование во всем объеме. Смешанная алюмосиликатная система с соотношением 1:13 была изучена более подробно. Выпавший осадок отделяли на центрифуге в течение 30 мин ( $\mathrm{W}=10000$ об./мин). Центрифугат анализировали на предмет содержания $\mathrm{SiO}_{2}$ и $\mathrm{Al}_{2} \mathrm{O}_{3}$. Содержание оксида кремния определяли гравиметрическим методом (осаждали $\mathrm{HCl}$ ). Содержание оксида алюминия определяли титриметрическим методом. Относительное уменьшение содержания оксидов алюминия и кремния составило $43 \%$ и $22 \%$ соответственно. Следовательно, и в этом случае во взаимодействии участвуют обе дисперсии. Этот факт означает, что процесс имеет гетерокоагуляционный характер.

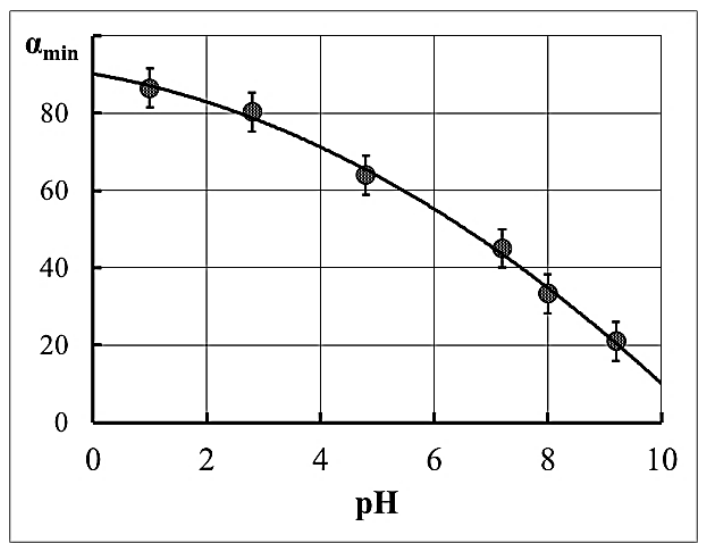

Рис. 12. Положение точки минимума на зависимостях времени жизни алюмосиликатной дисперсии от рН исходной активной кремневой кислоты (amin - содержание $\mathrm{Al2O3}$ в алюмосиликатной дисперсии)

Суспензии гидроксида алюминия обладают важным специфическим свойством, которое заключается в практически полном отсутствии 
возможности изменения заряда частиц исходного гидроксида алюминия с помощью корректировки $\mathrm{pH}$. Мы можем влиять на ее устойчивость только при ее синтезе, изменяя содержание анионов в системе.

Таким образом, исследование влияния перечисленных факторов на свойства сложной алюмосиликатной дисперсии дает возможность управлять ее устойчивостью, однородностью и обеспечивать протекание процесса по гетерокоагуляционному пути. Этот факт наиболее важен при синтезе и использовании композиционных флокулянтов-коагулянтов.

\section{7. Характеристика природных вод}

Большинство рек России являются маломутными водами гидрокарбонатного класса кальциевой группы и отличаются цветностью, щелочностью и жесткостью ${ }^{82,83}$. В период паводков в большинстве рек повышается мутность и цветность и снижается жесткость и щелочность. В зимнее время понижается температура воды. Цветность является одним из основных нормируемых показателей качества очищенной воды. Это связано с тем, что при хлорировании цветных вод могут образовываться высокотоксичные хлорорганические соединения, поэтому исследование коагулирующей способности коагулянтов АКФК и ФКФК проводилось на природных речных водах с малой мутностью их трех рек, а именно Орши, Волги и Тверцы. Эти воды отличаются показателем цветности, и их характеристики представлены в табл. 4.

Таблица 4

Характеристики речных вод

\begin{tabular}{|c|c|c|c|c|}
\hline Показатель & $\begin{array}{c}\text { Единица } \\
\text { измерения }\end{array}$ & Р. Волга & Р. Тверца & Р. Орша \\
\hline рН & & 7,75 & 7,78 & 7,48 \\
\hline Щелочность & мг-экв/л & 2,15 & 1,9 & 2,4 \\
\hline Мутность & мг/л & 10 & 12 & 25,6 \\
\hline Цветность* & град. & 85 & 102 & 288 \\
\hline
\end{tabular}

* иветность измерялась в градусах хром-кобальтовой икаль

82 Драгинский В.Л., Алексеева Л.П., Гетманцев С.С. Коагуляция в технологии очистки природных вод. Москва, 2005. 571 с.

83 Аксенов В.И., Гандурина Л.В., Керин А.С. и др. Водное хозяйство промышленных предприятий. Кн. 6 : Флокулянты. Москва : Теплотехник, 2008. $256 \mathrm{c}$. 
Как следует из табл. 4, речные воды Волги и Тверцы относятся к водам с малой мутностью и средним уровнем цветности, а речная вода Орши - к водам с высоким уровнем цветности.

\section{3. Эффективность применения композиционных коагулянтов АКФК и ФКФК для очистки природных вод}

\section{1. Сравнение коагулирующей способности коагулянтов при очистке воды с высокой цветностью р. Орши}

Результаты по эффективности снижения мутности (оптической плотности $\mathrm{D}_{540}$ ) и цветности (оптической плотности $\mathrm{D}_{400}$ ) оршинской воды в зависимости от дозы коагулянтов представлены на рис. 13-15. Как следует из полученных данных, для всех коагулянтов кривые зависимости мутности от дозы проходят через максимум, что свидетельствует об образовании при этих дозах очень мелких и плохо осаждаемых хлопьев. Оптимальные дозы алюмосодержащих коагулянтов АКФК и СА и железосодержащих коагулянтов ФКФК и ЖС (сульфат закисного железа), при которых наблюдается максимальное и практически одинаковое снижение мутности и цветности, равны и составляют 25 мг/л (по оксиду металла). Однако алюмосодержащие коагулянты лучше снижают мутность и цветность воды, чем железосодержащие, которые требуют также дополнительного подщелачивания очищаемой воды. При использовании АКФК и СА для очистки воды р. Орши не требуется корректировка величины $\mathrm{pH}$ очищаемой воды, которая монотонно и в равной степени снижается с увеличением дозы как АКФК, так и СА, как показано на рис. 13.

Как видно из представленных зависимостей, коагулянты ФКФК и ЖС дают низкий эффект обесцвечивания воды реки Орши, имеющей высокую цветность. Этот факт обусловлен, по всей вероятности, образованием полимерных карбокисилатных хелатных комплексов в результате химического взаимодействия ионов железа с гуминовыми кислотами либо образованием коллоидных соединений железа. Все эти соединения обладают высокой цветностью, что значительно влияет на показатели цветности проб очищенной воды. 


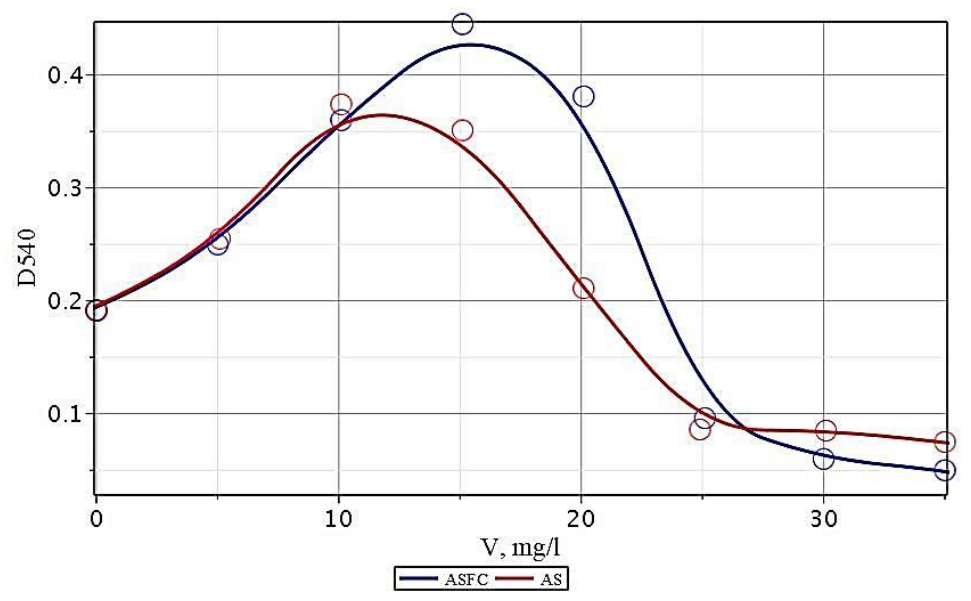

Рис. 13. Зависимость мутности (D540) коагулированной и отстоянной воды р. Орши с применением АКФК (ASFC) и сульфата алюминия (AS) (V - доза коагулянта, мг/л)

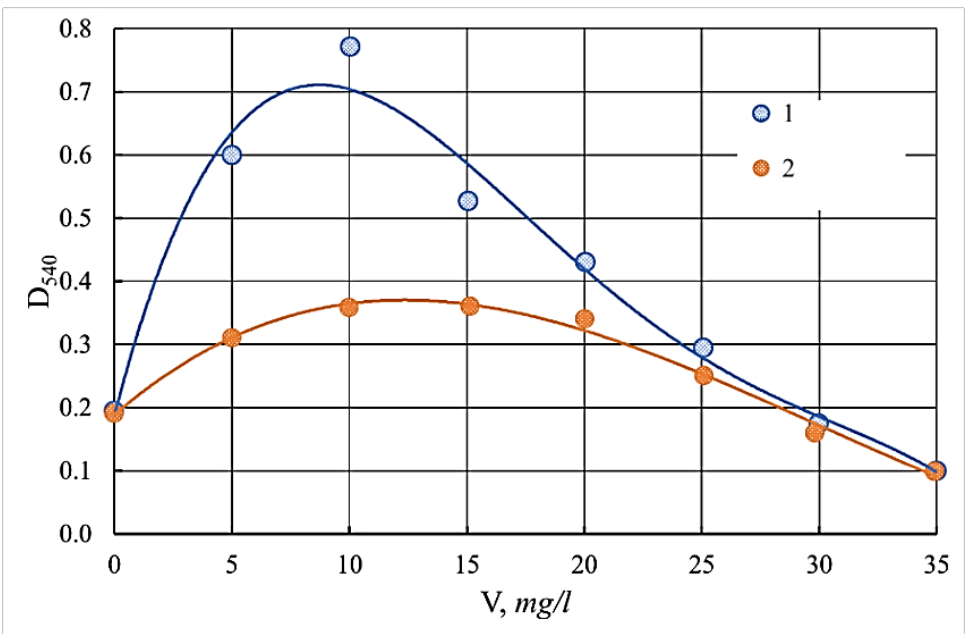

Рис. 14. Зависимость мутности (D540) коагулированной и отстоянной воды р. Орши с применением ЖКФК $(1, \mathrm{pH}=9,4)$ и сульфата железа (II) $(2, \mathrm{pH}=9,2)(\mathrm{V}$ - доза коагулянта, мг/л) 


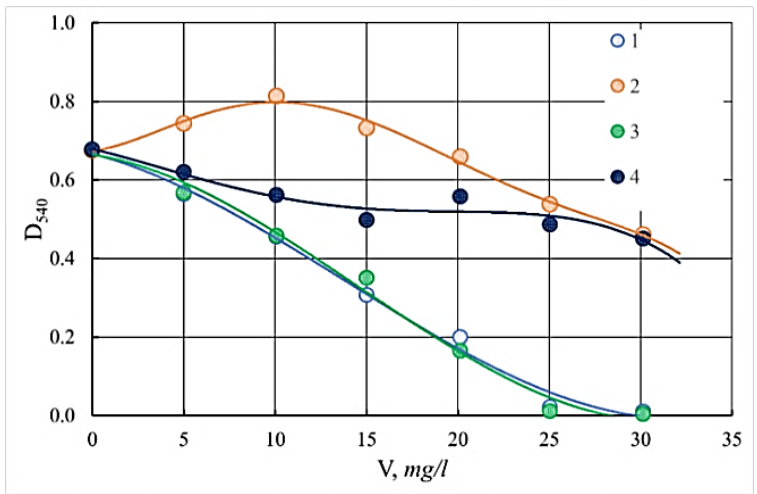

Рис. 15. Зависимость цветности (D400) коагулированной и отстоянной воды р. Орши с применением АКФК (1), ЖКФК (2, pH=9,4), сульфата алюминия (3) и сульфата железа (II) $(4, \mathrm{pH}=9,2)(\mathrm{V}$ - доза коагулянта, мг/л)

Типичное гуминовое вещество представляет собой смесь многих молекул, содержащих ароматические ядра с фенольными и карбоновыми заместителями, связанными вместе. Функциональными группами, которые в наибольшей степени способствуют поверхностному заряду и реакционной способности гуминовых веществ, являются фенольные и карбоксильные группы. Кроме того, гуминовые кислоты содержат множество компонентов в виде производных хинона, фенола, катехола и сахарных фрагментов ${ }^{84}$. Другой важной характеристикой является плотность заряда. Молекулы могут образовывать надмолекулярную структуру, удерживаемую вместе нековалентными силами, такими как сила Ван-дер-Ваальса, связи $\pi-\pi$ и $\mathrm{CH}-\pi^{85}$. Присутствие карбоксилатных и фенолятных групп дает гуминовым кислотам способность образовывать комплексы с ионами, такими как $\mathrm{Mg}^{2+}, \mathrm{Ca}^{2+}, \mathrm{Fe}^{2+}$ и $\mathrm{Fe}^{3+}$. Многие гуминовые кислоты имеют две или более из этих групп, расположенных таким образом, чтобы обеспечить образование хелатных комплексов ${ }^{86}$.

${ }^{84}$ Stevenson F.J. Humus Chemistry: Genesis, Composition, Reactions. New York : John Wiley \& Sons, 1994. 512 p. ISBN: 978-0-471-59474-1.

${ }^{85}$ Piccolo A. The supramolecular structure of humic substances: a novel understanding of humus chemistry and implications in soil science. Advances in agronomy. 2002. № 75. P. 57-134. DOI: 10.1016/s0065-2113(02)75003-7. AGR: IND23268553. ISBN 978-0-12-000793-6.

${ }^{86}$ Tipping E WHAM - a chemical equilibrium model and computer code for waters, sediments, and soils incorporating a discrete site/electrostatic model of ion-binding by humic substances. Computers and Geosciences. 1994. № 20 (6). P. 973-1023. DOI: 10.1016/0098-3004(94)90038-8. 
Для интенсификации очистки воды по мутности и цветности была использована добавка катионного флокулянта Праестол 650 (рис. 16, 17), который применяется на многих станциях водоподготовки для увеличения скорости осаждения скоагулированных загрязнений в сочетании с сульфатом алюминия.

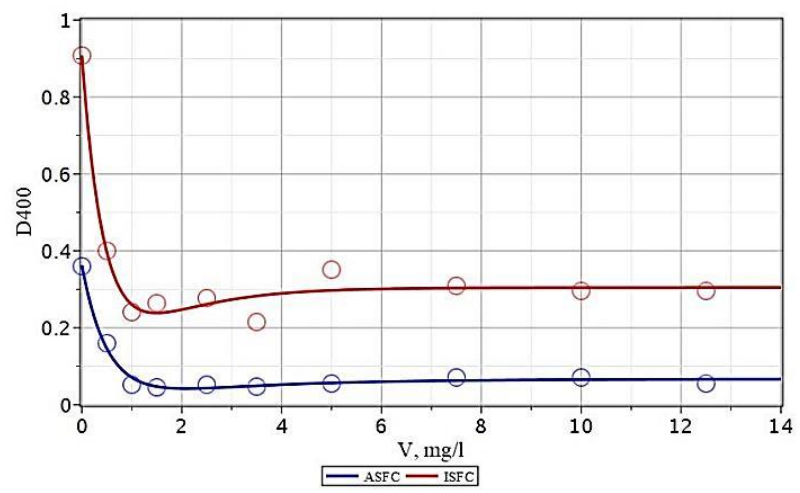

Рис. 16. Зависимость мутности (D540) коагулированной и отстоянной воды р. Орши с применением АКФК и ФКФК (20 мг/л) совместно с флокулянтом Праестол 650 от его дозы

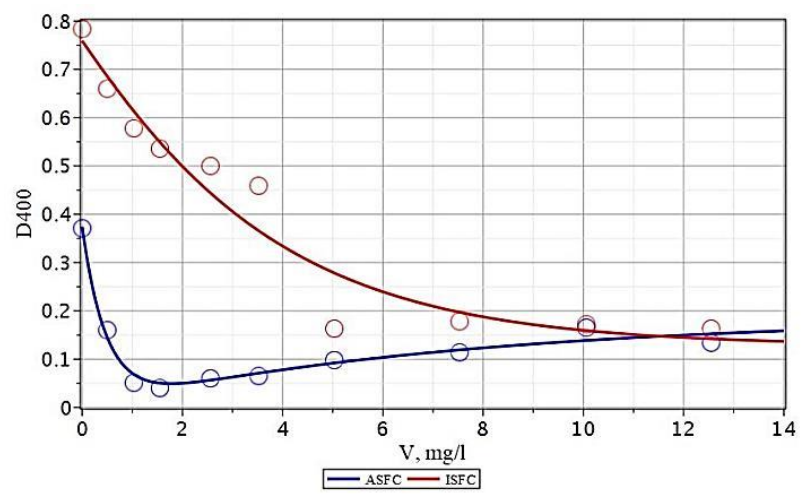

Рис. 17. Зависимость цветности (D400) коагулированной и отстоянной воды р. Орши с применением АКФК (ASFC) и ЖКФК (ISFC) (20 мг/л) совместно с флокулянтом Праестол 650 от его дозы

Представленные на рис. 16, 17 зависимости имеют сложный вид с экстремумом. Исходя из этого, видим, что эти зависимости 
складываются в результате протекания двух взаимно противоположных процессов, характеризующихся определенными равновесными состояниями при определенной концентрации реагирующих веществ. Полученные зависимости хорошо описываются таким уравнением (21):

$$
D_{\lambda}=a \cdot \exp (-b \cdot V)+c \cdot(1-\exp (-d \cdot V)) .
$$

Первый член уравнения (21) отвечает за поведение левой, ниспадающей части кривой, представленной на рис. 16 и 16. Второй член этого уравнения обеспечивает рост представленных зависимостей при больших дозах реагентов. Соотношение констант в этом уравнении обеспечивает возникновение экстремума. Можно предположить, что первый член уравнения (21) описывает образование и осаждение твердой фазы смешанных гидроксидов, а второй может быть ответственным за их частичную пептизацию и образование коллоидного раствора. Поскольку этот механизм справедлив как для АКФК, так и для ЖКФК, то, скорее всего, он носит достаточно фундаментальный характер и объясняется общими законами поведения коллоидных дисперсий. Как следует из рис. 16 и 17, оптимальная доза

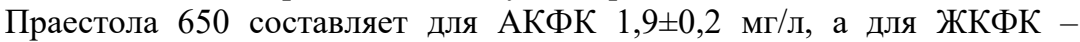
$1,5 \pm 0,2$ мг/л.

Зависимость мутности $\left(\mathrm{D}_{540}\right)$ очищенной воды р. Орши от дозы коагулянта при отношении доз коагулянта и дополнительного флокулянта Праестол 650, равного 20:1, представлена на рис. 18 и 19.

При этой концентрации достигается максимальное снижение мутности и цветности очищаемой воды. Кроме того, для достижения эффекта соответствующего АКФК для ЖКФК необходимо добавление значительного количества Праестола 650, равного 12 мг/л. Обнаруженное различие в поведении АКФК и ЖКФК при действии добавки Праестол 650 обусловлено различием строения формирующихся гидроксидов железа и алюминия. Так, при использовании более эффективного композиционного коагулянта АКФК, чем ФКФК, мутность воды снижается с 19,3 мг/л без дополнительного флокулянта до 8 мг/л с флокулянтом, а цветность уменьшается со 161 град. без флокулянта до 25,5 град. с добавкой флокулянта Праестол 650. 


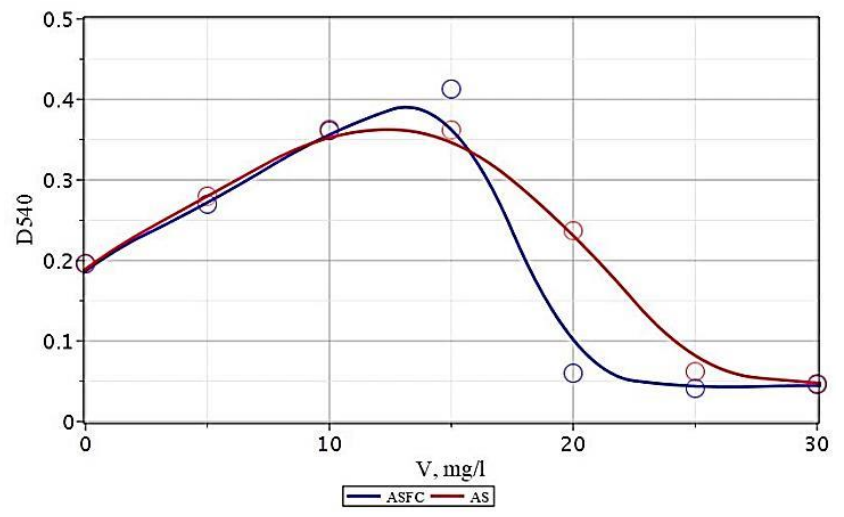

Рис. 18. Зависимость мутности (D540) очищенной воды р. Орши от дозы коагулянта при отношении доз коагулянта и дополнительного флокулянта равного 20:1 (АКФК - ASFC, сульфат алюминия - AS)

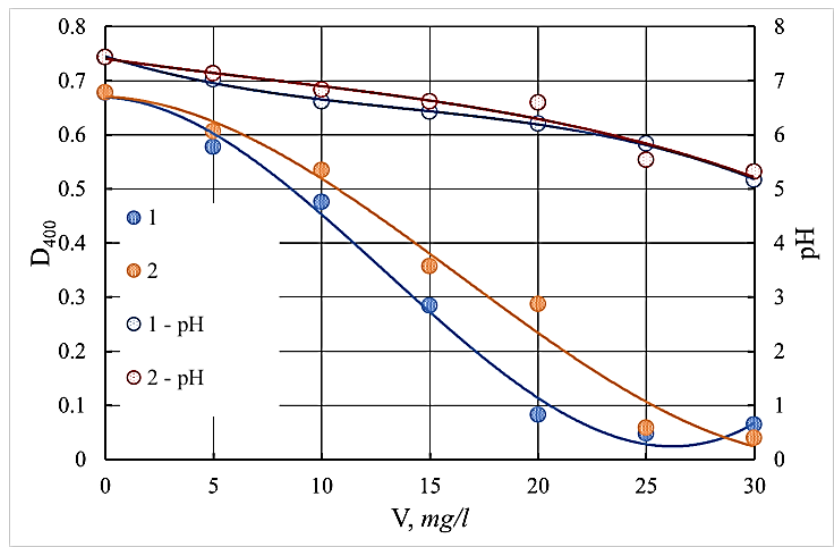

Рис. 19. Зависимость цветности (D400) и рН очищенной воды р. Орши от дозы коагулянта при отношении коагулянта и дополнительного флокулянта, равного 20:1

Сравнение действия композиционного коагулянта АКФК и сульфата алюминия при их использовании совместно с флокулянтом Праестол 650 для очистки воды реки Орши (рис. 18, 19) показывает, что АКФК значительно эффективнее, чем сульфат алюминия. АКФК снижает мутность и цветность и при меньшей дозе реагентов $(20 \pm 1$ мг/л). При использовании сульфата алюминия требуются более 
высокие дозы реагента $(25,0 \pm 1,3$ мг/л) для получения того же качества очищенной воды по мутности (78 мг/л) и цветности $(25 \div 31$ мг/л).

Таким образом, для очистки воды с высокой цветностью и малой мутностью, какой является речная вода реки Орши, эффективнее применять композиционный коагулянт АКФК совместно с Праестолом 650, чем ФКФК и сульфата алюминия.

\section{2. Сравнение коагулирующей способности коагулянтов при очистке воды р. Волги со средней цветностью}

Экспериментальные результаты, полученные по эффективности применения композиционных коагулянтов АКФК, ЖКФК и базовых коагулянтов, то есть сульфатов алюминия и железа закисного, для очистки Волжской воды, представлены на рис. 20-25.

Как следует из полученных данных, для снижения цветности исходной воды реки Волги по сравнению с водой реки Орши требуются меньшие дозы коагулянтов для достижения оптимальных условий. При этом достигается максимальный эффект снижения мутности и цветности. Если для очистки воды реки Орши дозы коагулянтов составляли $20 \div 25$ мг/л, то для волжской воды $-12,5 \div 15$ мг/л. Внешний вид зависимостей мутности и цветности от дозы не изменился. Зависимость мутности очищенной воды от дозы коагулянта проходит через максимум (рис. 20). Такое поведение свидетельствует о низкой скорости осаждения скоагулированных загрязнений и необходимости дополнительного фильтрования воды. Также возможно применение дополнительных флокулянтов для укрупнения скоагулированных загрязнений и увеличения скорости их осаждения в процессе отстаивания.

Цветность очищаемой воды монотонно снижается с увеличением дозы АКФК и достигает минимума (8,5 град.) при дозе 17,5 мг/л (рис. 21). Значение цветности очищенной воды, равная 19 град., что ниже нормируемой величины (20 град.), достигается при дозе АКФК 12,5 мг/л, при которой СА обеспечивает остаточную цветность в 23,3 град. (рис. 20).

Применение коагулянтов в сочетании с флокулянтом Праестол 650 сопровождается увеличением эффекта очистки воды по мутности при использовании как АКФК, так и СА. Оптимальная доза флокулянта составляет 0,5 мг/л при дозе коагулянтов 15 мг/л (рис. 22, 23). Остаточная мутность составляет 2,68 мг/л при использовании АКФК и 1,34 мг/л при коагуляции сульфатом алюминия, тогда как без флокулянта мутность отстоянной воды составляет 16,7-19,4 мг/л. В случае применения АКФК для достижения мутности, равной 1,34 мг/л, доза флокулянта должна быть повышена до 0,75 мг/л (рис. 23). 


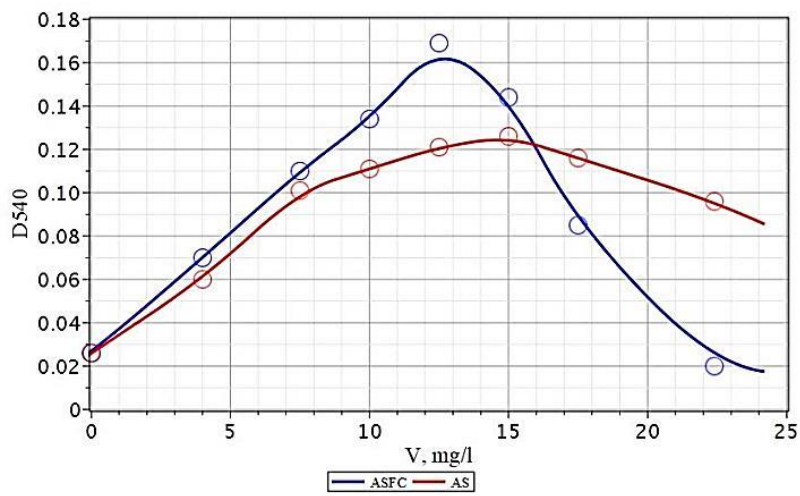

Рис. 20. Зависимость мутности (D540) коагулированной и отстоянной воды р. Волги с применением АКФК (ASFC) и сульфата алюминия (AS) ( V - доза коагулянта, мг/л)

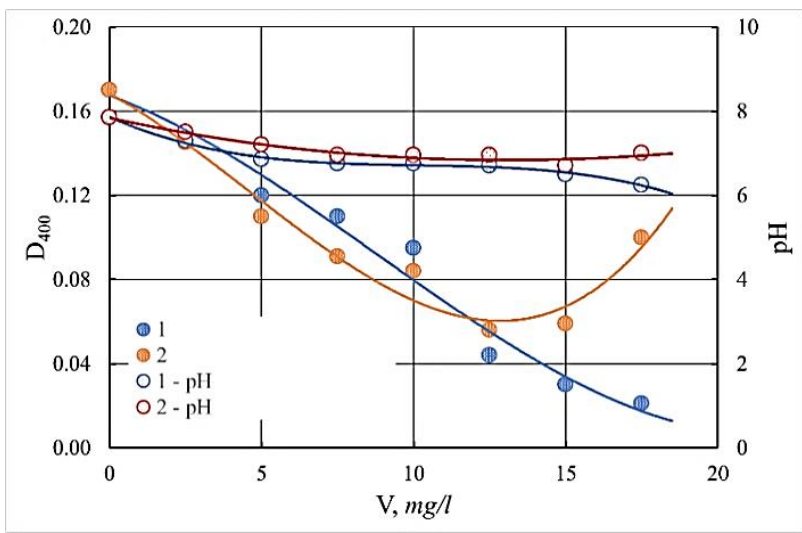

Рис. 21. Зависимость цветности (D400) и рН очищенной воды реки Волги от дозы коагулянта, соотношение коагулянта и дополнительного флокулянта, равного 20:1 (V - доза коагулянта, мг/л)

Цветность волжской воды лучше снимается при использовании АКФК, чем СА, как при самостоятельном использовании коагулянтов, так и в сочетании с флокулянтом Праестол 650 (рис. 21, 23).

Как следует из рис. 24, 25, железосодержащие коагулянты увеличивают цветность и мутность исходной воды. Такие эффекты наблюдаются как при самостоятельном применении, так и совместно с флокулянтом. Они обусловлены образованием гуматных комплексов 
с ионами железа или образованием коллоидных форм продуктов гидролиза сульфата железа, которые имеют высокую цветность.

Увеличение величины $\mathrm{pH}$ очищаемой воды при использовании ФКФК способствует снижению остаточной мутности, цветности и растворенного железа (рис. 26). Максимальное снижение мутности и цветности происходит в щелочной области при рН более 9,0.

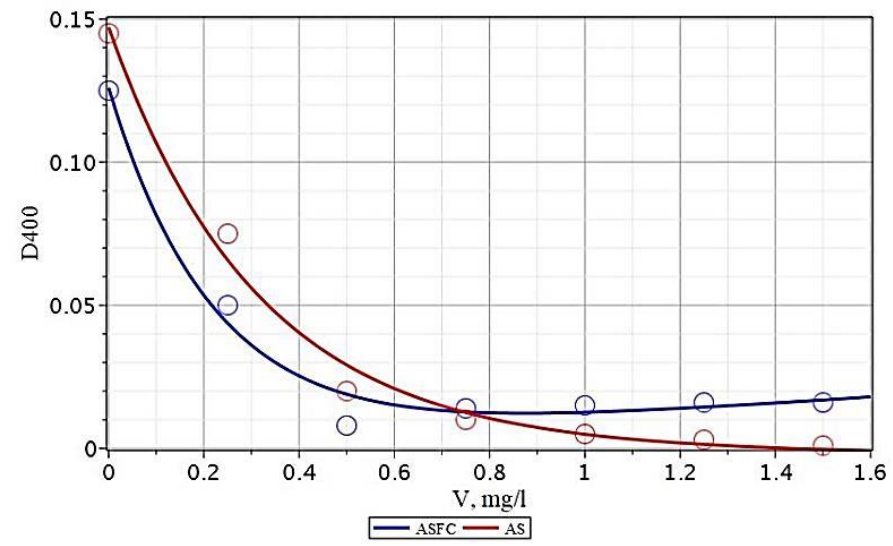

Рис. 22. Зависимость мутности D540 отстоянной воды реки Волга от дозы дополнительного флокулянта Праестол 650 при дозе коагулянта 15 мг/л (V - доза коагулянта, мг/л)

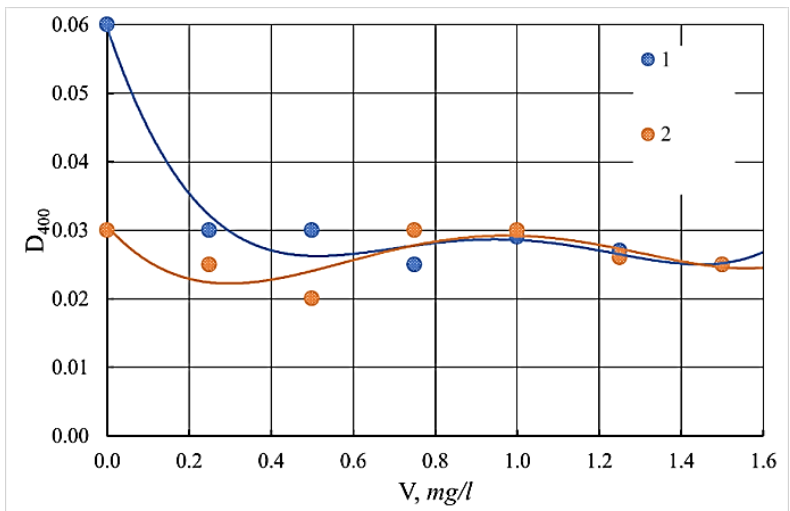

Рис. 23. Зависимость цветности D400 отстоянной воды р. Волга от дозы дополнительного флокулянта Праестол 650 при дозе коагулянта 15 мг/л (1 - АКФК; 2 - сульфат алюминия; $\mathrm{V}$ - доза коагулянта, мг/л) 


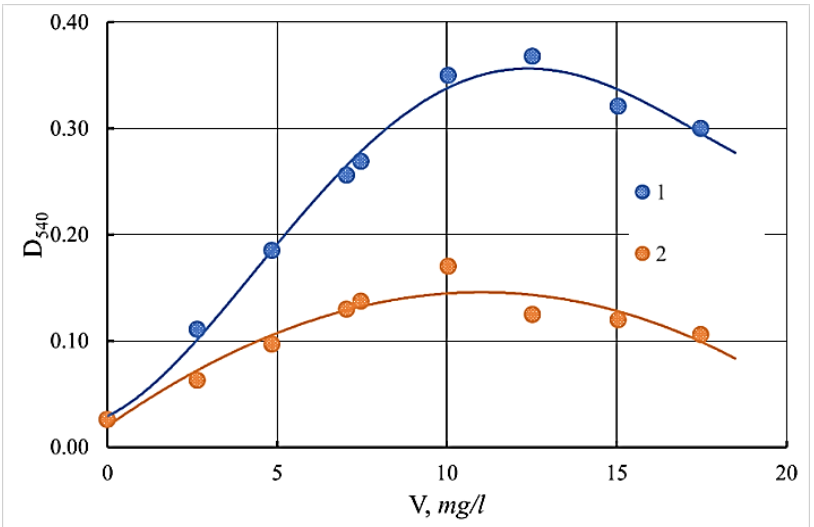

Рис. 24. Зависимость мутности D540 отстоянной воды реки Волги от дозы коагулянта-флокулянта ЖКФК (1 - индивидуальный ЖКФК;

2 - ЖКФК совместно с дополнительным флокулянтом Праестол 650 в отношении 20:1; V - доза коагулянта, мг/л)

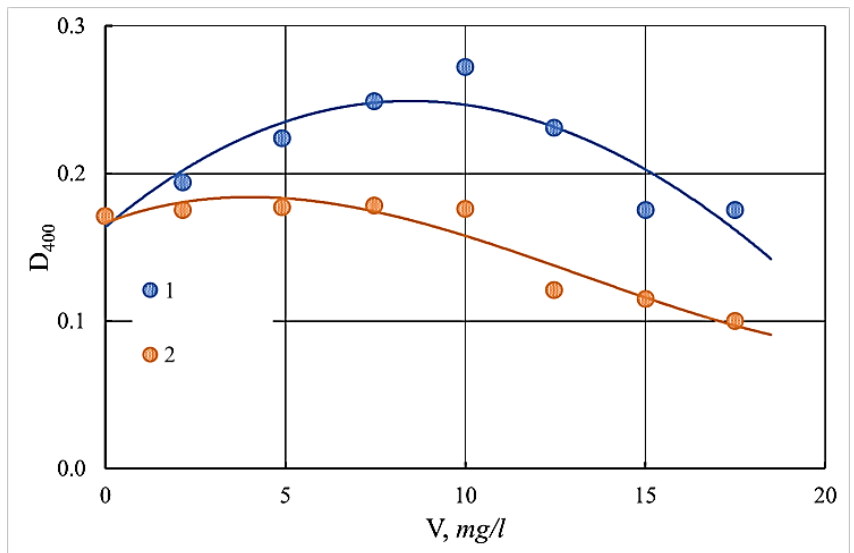

Рис. 25. Зависимость цветности D400 отстоянной воды реки Волги от дозы коагулянта-флокулянта ЖКФК (1 - индивидуальный ЖКФК;

2 - ЖКФК совместно с дополнительным флокулянтом Праестол 650 в отношении 20:1; V - доза коагулянта, мг/л) 


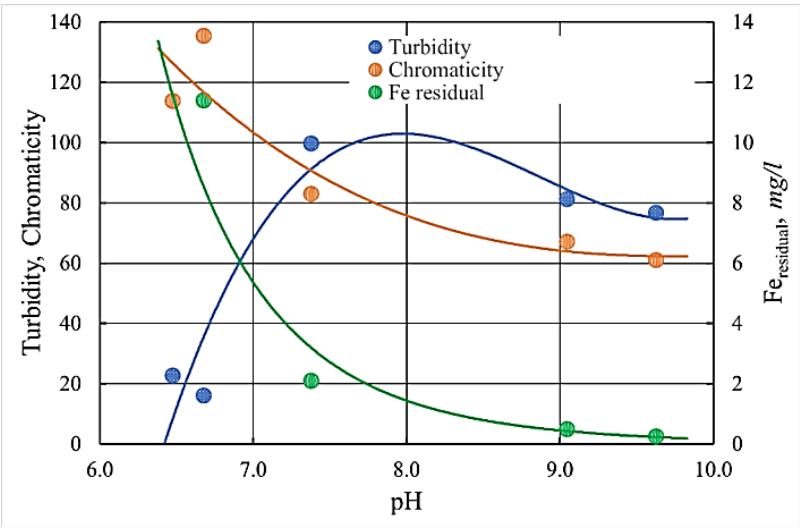

Рис. 26. Зависимость качества скоагулированной и отстоянной воды р. Волга от рН с применением ФКФК с дозой 15 мг/л при температуре $10^{\circ} \mathrm{C}$

Результаты, представленные на рис. 26, показывают, что при очистке волжской воды, как и оршинской, более эффективными являются алюмосодержащие коагулянты при их использовании в сочетании с катионным флокулянтом Праестол 650. При этом композиционный коагулянт АКФК по сравнению с сульфатом алюминия лучше снижает цветность воды, а в совокупности с флокулянтом - также мутность волжской воды.

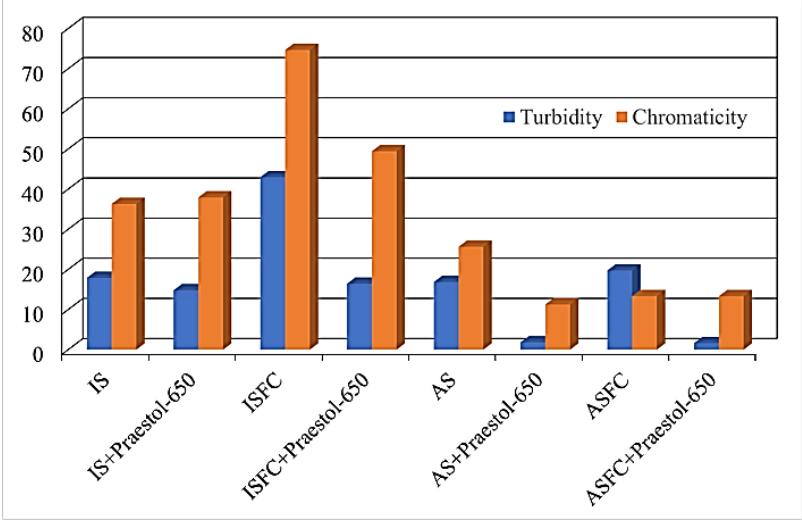

Рис. 27. Эффективность снижения цветности и мутности воды р. Волга коагулянтами (15 мг/л) и совместно с дополнительным флокулянтом Праестол 650 (0,75 мг/л) 


\section{3. Сравнение коагулирующей способности коагулянтов при очистке воды средней цветности реки Тверцы}

Поверхностные воды реки Тверцы близки по химическому составу волжской воде (табл. 2), поэтому можно предположить, что эффективность применения коагулянтов для очистки рек Тверцы и Волги будет близкой.

Полученные результаты, представленные на рис. 28-31, подтверждают это предположение, несмотря на то, что температура обрабатываемой воды р. Тверцы была $10^{\circ} \mathrm{C}$, что в 2 раза ниже, чем волжской воды $\left(20^{\circ} \mathrm{C}\right)$. Оптимальные дозы сульфат алюминия и АКФК, при которых максимально удаляется цветность, одинаковы и равны 12,5 мг/л (рис. 29). Остаточная цветность составляет 21-23 град. Кривые мутности также проходят через максимум (рис. 28), как и при коагуляционной очистке волжской воды.

При применении ФКФК эффективность очистки зависит от $\mathrm{pH}$ воды. Наибольшее снижение мутности и особенно цветности очищаемой воды р. Тверцы наблюдается при $\mathrm{pH}$ 9,3 и дополнительном введении дополнительного флокулянта Праестол 650 при таком отношении коагулянт: флокулянт $=20$ (рис. 29).

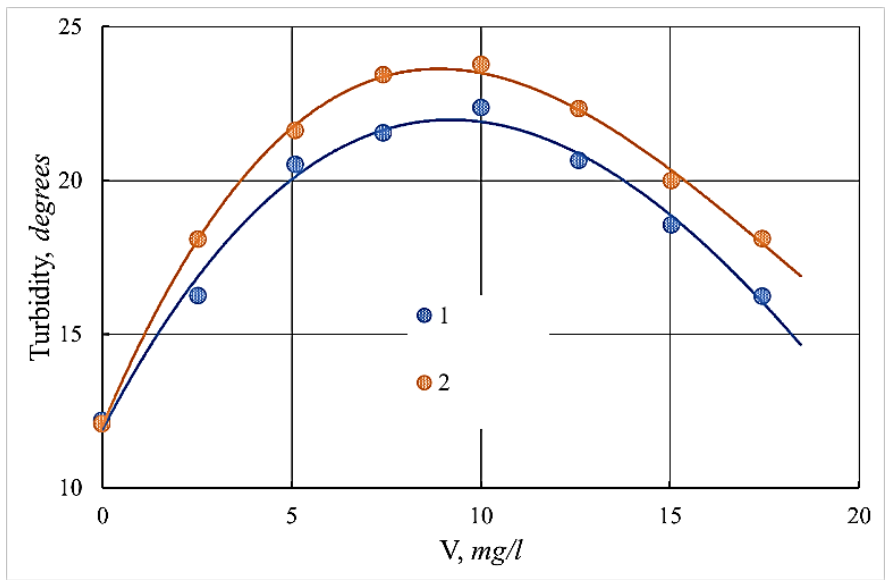

Рис. 28. Зависимость мутности отстоянной воды р. Тверца от дозы коагулянта (1 - АКФК; 2 - сульфат алюминия; V - доза коагулянта, мг/л) 


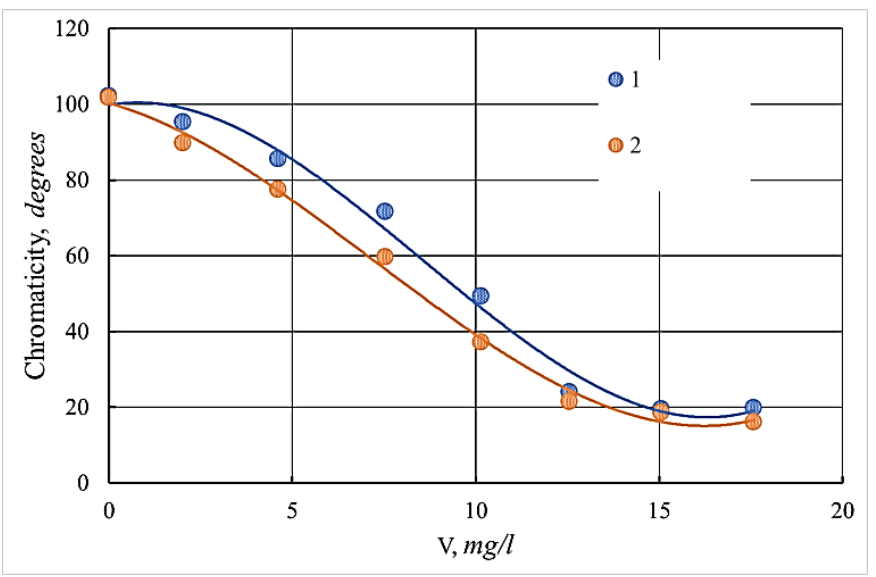

Рис. 29. Зависимость цветности отстоянной воды р. Тверцы от дозы коагулянта (1 - АКФК; 2 - сульфат алюминия; V - доза коагулянта, мг/л)

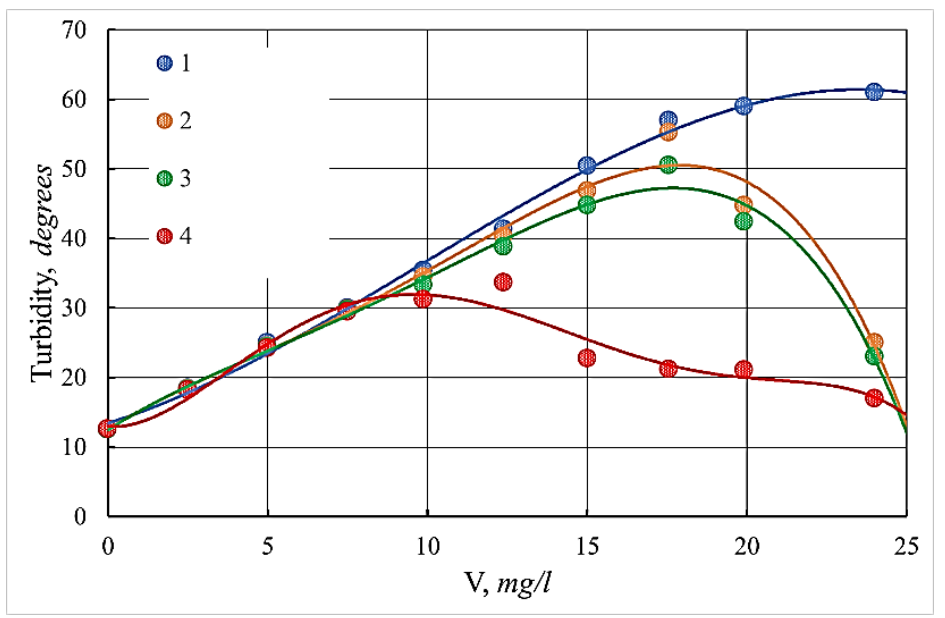

Рис. 30а. Зависимость мутности скоагулированной воды реки Тверцы от дозы ФКФК при разных рН обрабатываемой воды 


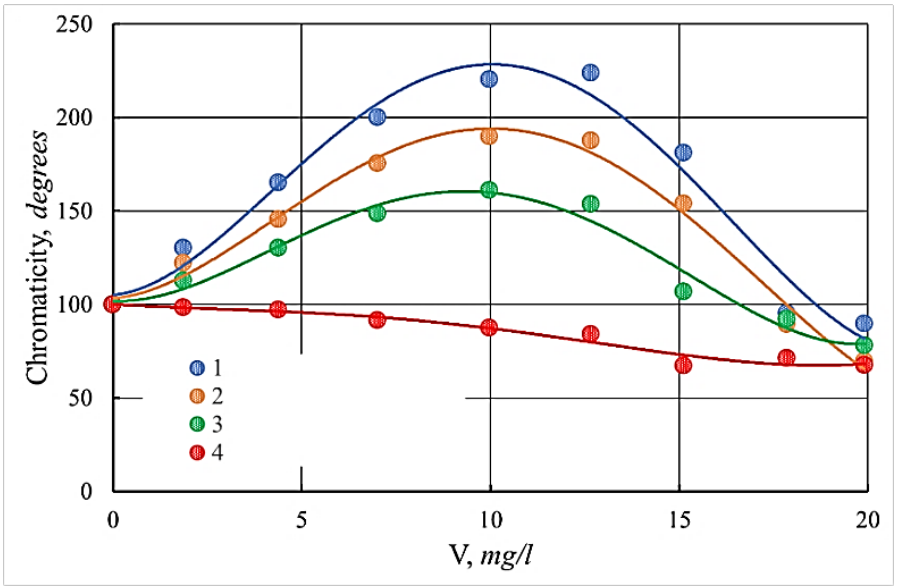

Рис. 30б. Зависимость цветности скоагулированной и отстоянной воды реки Тверцы от дозы ФКФК при разных рН обрабатываемой воды

Применение флокулянта дозой 0,35-0,5 мг/л увеличивает эффект очистки по мутности при отстаивании в большей степени, чем по цветности (рис. 31, 32).

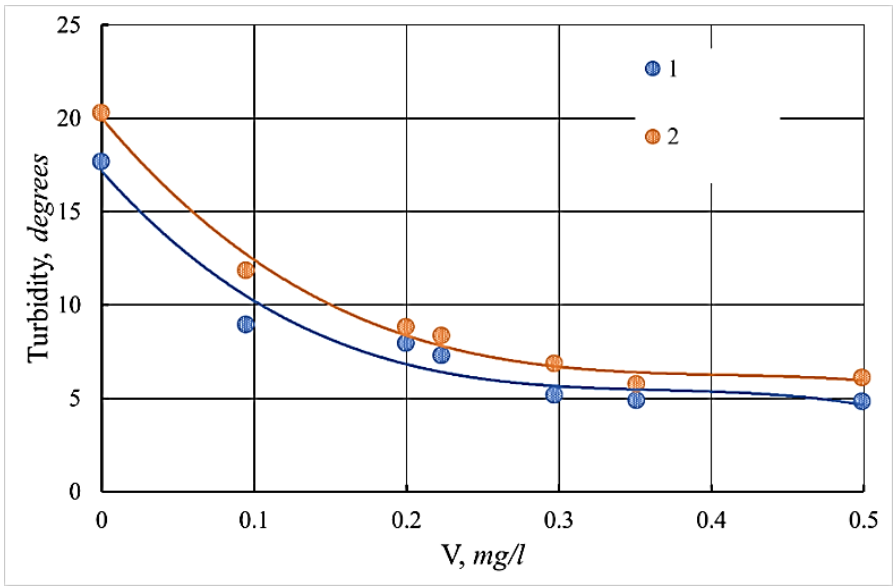

Рис. 31. Зависимость мутности отстоянной воды р. Тверцы от дозы добавочного флокулянта Праестол 650 при дозе коагулянта 12,5 мг/л (1-AКФК; 2 -сульфат алюминия; V-доза коагулянта, мг/л) 


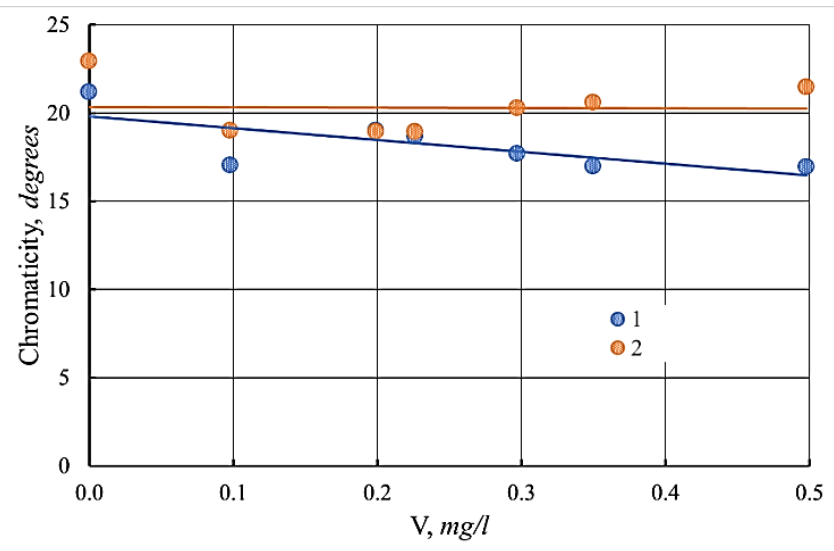

Рис. 32. Зависимость цветности отстоянной воды р. Тверцы от дозы добавочного флокулянта Праестол 650 при дозе коагулянта 12,5 мг/л

(1 - АКФК; 2 - сульфат алюминия; V - доза коагулянта, мг/л)

Содержание статочного алюминия в воде минимально при оптимальной дозе коагулянтов (рис. 33), но несколько выше при применении АКФК, чем сульфат алюминия, хотя и в том, и в другом случаях в 5 и более раз ниже нормы (0,5 мг/л).

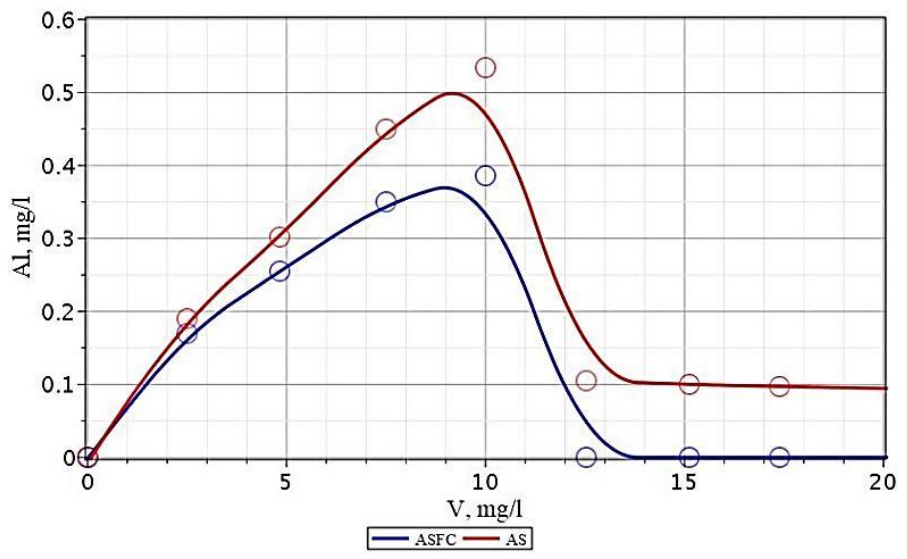

Рис. 33. Зависимость содержания остаточного алюминия в отстоянной воде р. Тверцы от дозы коагулянта 
Таким образом, композиционные коагулянты АКФК и ФКФК и базовые коагулянты, а именно сульфаты алюминия и железа, проявляют близкие коагулирующие свойства при очистке природных вод разных водоисточников.

\section{ВЫВОДЫ}

Экспериментально показано, что композиционный флокулянт АКФК эффективнее сульфата алюминия при очистке маломутных вод с высокой и средней цветностью по показателю цветности при равных или меньших дозах. Одновременное достижение высокого показателя очистки воды отстаиванием по цветности и мутности достигается при применении АКФК совместно с флокулянтом Праестол 650 при соотношении коагулянт/флокулянт 20:1.

Композиционный коагулянт ФКФК и сульфат железа не обеспечивают требуемого эффекта очистки природных вод по цветности даже в щелочной среде, что делает их применение в существующих схемах водоподготовки нецелесообразным. Их применение возможно в технологиях очистки природных вод с малой цветностью при условии создания специальных более жестких условий коагуляции и перевода двухвалентного железа в трехвалентное, а также для очистки сточных вод от солей тяжелых металлов.

\section{АННОТАЦИЯ}

Коагуляция является важным процессом при очистке воды и промышленных сточных вод. В области очистки питьевой воды с древних времен практикуется очищение воды с помощью коагулянтов с использованием различных веществ. Коагуляция является самым распространенным методом очистки природных и сточных вод от основной массы коллоидных, тонкодисперсных и частично растворенных загрязнений. Представлены характеристики разработанных авторами новых композиционных флокулянтов-коагулянтов АКФК и ЖКФК в сравнении с обычными солями алюминия и железа. Методом титрования исследовано поведение флокулянтов-коагулянтов при различных $\mathrm{pH}$. В этих условиях исследовано изменение буферной емкости, проведены турбидиметрические исследования флокулянтовкоагулянтов. Определены ל-потенциалы и изоэлектрические точки для гидроксида алюминия, полученного при гидролизе коагулянта. Показан характер взаимодействия активной кремневой кислоты и продуктов гидролиза солей алюминия как компонентов композиционных флокулянтов-коагулянтов. Приведены характеристики природных вод, на которых исследована эффективность использования полученных флокулянтов-коагулянтов. Представлено сравнение коагулирующей 
способности коагулянтов при очистке воды с высокой цветностью из реки Орша и со средней цветностью из рек Волга и Тверца.

\section{БЛАГОДАРНОСТИ}

Авторы выражают свою благодарность руководителю лаборатории реагентных методов очистки воды Комплексного научноисследовательского и конструкторско-технологического института водоснабжения, канализации, гидротехнических сооружений и инженерной гидрогеологии ОАО «НИИ ВОДГЕО», д.Х.н. Л.В. Гандуриной за помощь в проведении испытаний композиционных флокулянтов-коагулянтов.

\section{ЛИТЕРАТУРА}

1. Запольский А.К., Баран А.А. Коагулянты и флокулянты в процессах очистки воды. Свойства. Получение. Применение. Ленинград : Химия, 1987. 208 с.

2. Кручинина Н.Е., Турниер В.Н., Лисюк Б.С., Ким В. Способ получения алюмосиликатного коагулянта. Пат. РФ № 2225838, 26.11.02.

3. Кручинина Н.Е. АКФК как альтернатива традиционным коагулянтам в процессах водоочистки и водоподготовки. Экология производства. 2006. № 2. С. 46-50.

4. Недугов А.Н., Волкова М.А., Кайсин А.В., Кудрявцев П.Г., Кудрявцев Н.П., Порошина Н.В., Рябов В.А. Способ получения композиционного алюмокремниевого флокулянта-коагулянта. Патент РФ № 2447021, по заявке № 2010133345/05, МПК, С01B33/26, С02F1/52, C01F7/74. Бюл. 09.08.2010.

5. Cradock S., Hinchcliffe A.J. Matrix Isolation. A Technique for the Study of Reactive Inorganic Species, Cambridge Universty Press, Cambridge, 1975.

6. Кудрявцев П.Г., Недугов А.Н., Рябов В.А., Волкова М.А., Кайсин А.В., Коротаев И.М., Коркин А.М. Способ получения алюмокремниевого флокулянта-коагулянта и способ очистки с его помощью воды. Патент РФ № 2388693 МПК, С01B33/26, C01F7/74, С02F1/52. Бюл. 28.07.2008.

7. Волкова М.А., Дегтев М.И., Кудрявцев П.Г., Недугов А.Н., Кайсин А.В., Андриенко С.В. Новый высокотехнологичный алюмокремниевый флокулянт-коагулянт как альтернатива известным реагентам водоочистки. Актуальные проблемы химической науки, практики и образования : сборник статей Международной научнопрактической конференции, 19-21 мая 2009 года. Ч. 2. С. 19-22. 
8. Волкова М.А., Дегтев М.И., Кудрявцев П.Г., Недугов А.Н., Кайсин А.В., Андриенко С.В. Новый высокотехнологичный алюмокремниевый флокулянт-коагулянт как альтернатива известным реагентам водоочистки. Сборник трудов ЕНИ при ПГУ. Пермь, 2010. C. $41-43$.

9. Недугов А.Н., Волкова М.А., Кайсин А.В., Кудрявцев П.Г., Кудрявцев Н.П., Порошина Н.В., Рябов В.А. Способ получения железокремниевого флокулянта-коагулянта и способ обработки воды. Патент РФ № 2438993, по заявке № 2010133344/05, МПК, C02F1/52, C01G49/14, C01B33/32, В01D21/01. Бюл. 09.08.2010.

10. Kudryavtsev P.G., Kudryavtsev N.P., Nedugov A.N., Volkova M.A., Kudryavtsev I.P. Solid Alumina-Silicon Flocculants-Coagulants Matrixisolated Nanocomposites. Technical chemistry, from theory to practice : IV International Conference, October 20-24, 2014. Perm. P. 38. DOI: $10.13140 /$ RG.2.1.2195.7283.

11. Kudryavtsev P.G., Kudryavtsev N.P., Kudryavtsev I.P. Nanocomposite alumina-silica-flocculants-coagulants, Current Issues of Ecological Safety: Cleaning of Water Sources and Air Basin; Recycling of Municipal Solid Waste, Book of Abstracts, p. 11, 2015, Jerusalem.

12. Kudryavtsev P.G. Kudryavtsev N.P. New high-tech composite flocculants-coagulants as an alternative to the known reagents for water treatment. Alternative Energy and Ecology (ISJAEE). 2016. № 11-12 (199200). P. 93-103. DOI: 10.15518/isjaee.2016.11-12.093-103.

13. Kudryavtsev P.G., Kudryavtsev N.P. New Composite Flocculants Coagulants as an Alternative to the Known Water Treatment Agents. Scientific Israel-Technological Advantages. 2016. Vol. 18. № 3. P. 84-97. ISSN: 1565-1533.

14. Kudryavtsev P.G., Kudryavtsev N.P. Matrix-isolated nanocomposites - alumina-silicon flocculants-coagulants. 34th IVS Annual Meeting, September 12th, 2016, Ben Gurion University of the Negev, Beer-Sheva. P. 112.

15. Kudryavtsev N., Kudryavtsev P., Figovsky O.L. Matrix-Isolated Smart Nanocomposite Materials - Alumina Silicon Flocculants Coagulants, 4th International Conference on Competitive Materials and Technology Processes, Miskolc-Lillafüred, Hungary, October 3-7, 2016. P. 134.

16. Kudryavtsev P.G., Kudryavtsev N.P., Figovsky O.L. Matrix-isolated nanocomposite flocculants, coagulants for purification of natural and waste waters from oil pollution. NANOTECHOILGAS - 2016 : Proceedings of the $\mathrm{V}$ International Scientific and Practical Conference. Moscow, November 22-24, 2016. Moscow, Oil \& Gas, 2016. P. 91-96.

17. Кудрявцев П.Г., Кудрявцев Н.П., Фиговский О.Л. Очистка промышленных и сточных вод с использованием матрично- 
изолированных нанокомпозиционных флокулянтов-коагулянтов. DOI: dx.doi.org/10.15828/2075-8545-2017-9-3-44-61. Нанотехнологии в строительстве. 2017. Vol. 9. № 3. C. 44-61. DOI: dx.doi.org/10.15828/2075-8545-2017-9-3-44-61 (in Russian).

18. Kudryavtsev P., Figovskiy O. Matrix-Isolated Nanocomposites Alumina-Silicon Flocculants-Coagulants. Journal of Physical Science and Application. 2017. Vol. 7. № 3. P. 25-36. DOI: 10.17265/21595348/2017.03.003.

19. Kudryavtsev P., Figovsky O., Kudryavtsev N. Cleaning of natural and sewage water using new composite flocculants coagulants. Engineering Journal of Don. 2017. № 4. C. 1-18. ISSN 2073-8633, ivdon.ru/ru/magazine/archive/n4y2017/4572.

20. Кудрявцев П.Г., Кудрявцев Н.П. Очистка сточных вод с использованием матрично-изолированных нанокомпозиционных флокулянтов-коагулянтов. Инженерный вестник Дона. 2018. № 3. C. 1-32. ISSN 2073-8633, ivdon.ru/ru/magazine/archive/n3y2018/5045.

21. Cohen J.M., Hannah S.A. Coagulation and flocculation, Water Quality and Treatment. Handbook of Public Water Supplies. 3d ed. McGraw-Hill BookCompany, New York, 1971. P. 66-122.

22. Bratby J. Coagulants, in Coagulation and Flocculation in Water and Wastewater Treatment. 2nd ed. IWA Publishing, London, 2006. P. 50-68.

23. Драгинский В.Л., Алексеева Л.П., Гетманцев С.С. Коагуляция в технологии очистки природных вод. Москва, 2005. $571 \mathrm{c}$.

24. Кульский Л.А., Строкач П.П. Технология очистки природных вод. Киев : Высшая школа, 1986. 352 с.

25. Tipping E. WHAM - a chemical equilibrium model and computer code for waters, sediments, and soils incorporating a discrete site/electrostatic model of ion-binding by humic substances. Computers and Geosciences. 1994. № 20 (6). C. 973-1023. DOI: 10.1016/00983004(94)90038-8.

26. Бабенков Е.Д. Очистка воды коагулянтами. Москва : Наука, 1977. $355 \mathrm{c}$.

27. Линевич С.Н., Гетманцев С.В. Коагуляционный метод водообработки. Теоретические основы и практическое использование. Москва : Наука, 2007. 230 с.

28. Драгинский В.Л. Повышение эффективности реагентной обработки воды на водопроводных станциях. BCT / Водоснабжение $u$ санитарная техника. 2000. № 5. С. 11.

29. Гетманцев С.В. Состояние производства и импорта алюмосодержащих коагулянтов в России. ВCT / Водоснабжение $u$ санитарная техника. 2003. № 2. С. 5. 
30. Коагулянты и флокулянты: анализ и оценка современного технологического уровня производства : аналитический обзор. Черкассы : Черкасский НИИТЭХИМ, 2001. 37 с.

31. Гетманцев С.В., Мясников И.Н., Потанина В.А., Сычев А.В. Использование алюмосодержащих коагулянтов в Северо-Западном федеральном округе. Сообщение 2 : Технология применения полиоксихлоридов алюминия для доочистки воды. Вода и экология. 2002. № 2. C. 2.

32. Гумен С.Г., Дариенко И.Н., Евельсон Е.А., Русанова П.П. Применение современных химических реагентов для обработки маломутных цветных вод. ВCT / Водоснабжение $u$ санитарная техника. 2001. № 3. С. 12.

33. Храменков С.В., Благова О.Е. Использование современных коагулянтов и флокулянтов в системе Московского водопровода. ВCT / Водоснабжение и санитарная техника. 2001. № 3. С. 5.

34. Герасимов Г.Н. Процессы коагуляции-флокуляции при обработке поверхностных вод. ВСТ / Водоснабжение и санитарная техника. 2001. № 3. С. 26.

35. Клячко В.А., Апельцин И.Э. Очистка природных вод. Москва, $1971.579 \mathrm{c}$.

36. Вейцер Ю.И., Минц Д.М. Высокомолекулярные флокулянты в процессах очистки природных и сточных вод. Москва : Стройиздат, 1984. $201 \mathrm{c}$.

37. Аксенов В.И., Гандурина Л.В., Керин А.С. и др. Водное хозяйство промышленных предприятий. Кн. 6 : Флокулянты. Москва : Теплотехник, 2008. $256 \mathrm{c}$.

38. Новикова И.А., Бортышевский В.А., Кашковский В.И., Войновский В.В. Использование высокоэффективных коагулянтов при очистке воды. Экотехнологии и ресурсосбережение. 2002. № 3. С. 52.

39. Кручинина Н.Е., Тимашева Н.А., Шибеши А.К., Волкова И.И., Васильева Е.С. Алюмокремниевые флокулянты-коагулянты в очистке сточных вод пищевой промышленности. Вода: экология и технология : тезисы. Москва : УН Международный конгресс, 2006. 603 с.

40. Розенталь О.М., Кардашина Л.Ф. Химия, технология и сертификация неорганических материалов, применяемых в водном хозяйстве. Екатеринбург : УрО РАН, 1998. 252 с.

41. Литвинов А.И. Интенсификация технологии приготовления и применения активированной кремниевой кислоты при очистке южных рек : автореф. дисс. ... канд. техн. наук. Вологда, 2005. 23 с.

42. Гетманцев С.В., Нечаев И.А., Гандурина Л.В. Очистка производственных сточных вод коагулянтами и флокулянтами. Москва : АCB, 2008. 272 с. 
43. Brown P.L., Ekberg C. Hydrolysis of Metal Ions. Vol. 2, 2016 Wiley-VCH Verlag GmbH \& Co., 945 p. ISBN: 978-3-527-33010-2.

44. Brown P.L., Sylva R.N., Ellis J., Batley G.E. The hydrolysis of metal ions. P. 8 : Aluminium (III). J. Chem. Soc., Dalton Trans., 1967-1970.

45. Baes C.F., Mesmer R.E. The Hydrolysis of Cations, John Wiley \& Sons, Inc., New York, 1976.

46. Kudryavtsev P. Aluminum Hydroxide Based Anion Exchange Materials. Scientific Israel-Technological Advantages. 2020. Vol. 22. No. 1.

47. Skoog D.A., West D.M., Holler F.J., Crouch S.R. Fundamentals of Analytical Chemistry. 9th ed. Brooks/Cole, 2014. 226 p. ISBN 978-0-495-55828-6.

48. Urbansky E.T., Schock M.R. Understanding, Deriving and Computing Buffer Capacity. Journal of Chemical Education. 2000. № 77 (12). P. 1640-1644. DOI: 10.1021/ed077p1640.

49. Butler J.N. Ionic Equilibrium: Solubility and $\mathrm{pH}$ calculations. Wiley, 1998. P. 133-136. ISBN 978-0-471-58526-8.

50. Hulanicki A. Reactions of acids and bases in analytical chemistry / trans. by M.R. Masson. Horwood, 1987. ISBN 978-0-85312-330-9.

51. Фролов Ю.Г. Курс коллоидной химии. Поверхностные явления и дисперсные системы. Москва : Химия, 1988. 464 с. ISBN 5-7245-0244-5.

52.ГОСТ 18165-89, Вода питьевая. Метод определения массовой концентрации алюминия. Дата введения: 01.01.1991.

53.ГОСТ 4011-72. Вода питьевая. Методы измерения массовой концентрации общего железа (с Изменениями № 1, 2). Дата введения: 01.01.1974.

54. ГОСТ Р 57164-2016, Вода питьевая. Методы определения запаха, вкуса и мутности. Дата издания: 31.10.2016.

55. De Hek H., Stol R.J., De Bruyn P.L. Hydrolysis-precipitation studies of aluminum (III) solutions. 3. The role of the sulfate ion. Journal of Colloid and Interface Science. 1978. V. 64. Issue 1. P. 72-89. ISSN 0021-9797. DOI: https://doi.org/10.1016/0021-9797(78)90336-3.

56. Kudryavtsev P., Figovsky O. Nanomaterials based on soluble silicates. Monograph, LAP Lambert Academic Publishing, 2014, 241 p. ISBN 978-3-659-63556-4.

57. Sjöberg S., Nordin A., Ingri N. Equilibrium and structural studies of silicon (IV) and aluminium (III) in aqueous solution. II. Formation constants for the monosilicate ions $\mathrm{SiO}(\mathrm{OH})_{3}{ }^{-}$and $\mathrm{SiO}_{2}(\mathrm{OH})_{2}{ }^{2-}$. A precision study at $25^{\circ} \mathrm{C}$ in a simplified seawater medium. Marine Chemistry. 1981. Vol. 10. Issue 6. P. 521-532. DOI: https://doi.org/10.1016/0304-4203(81)90005-0.

58. Айлер Р. Химия кремнезема. Т. 1-2. Москва : Мир, 1982. 1127 с.

59. Hingston F.J., Raupach M. The reaction between monosilicic acid and aluminum hydroxide. I: Kinetics of adsorption of monosilicic acid by 
aluminum hydroxide. Austr. J. Soil Res. 1967. № 5. P. 295-309. DOI: https://doi.org/10.1071/SR9670295.

60. NanoPlus. Zeta Potential and Nano Particle Analyzer. Micromeritics Instrument Corp. URL: http://www.particulatesystems.com/Repository/ Files/NanoPlus_Brochure_Final_v8.pdf.

61. Кудрявцев П.Г., Кудрявцев Н.П., Фиговский О.Л. Растворимые соединения алюминия и нанокомпозитные материалы на их основе. Ч. ІІ. Нанотехнологии в строительстве. 2018. Т. 10. № 2. С. 63-85. DOI: dx.doi.org/10.15828/2075-8545-2018-10-2-63-85.

62. Kudryavtsev P., Kudryavtsev N. Nanocomposite materials based on soluble aluminum compounds. Scientific Israel-Technological Advantages. 2017. Vol. 19. № 3. P. 40-76. ISSN: 1565-1534.

63. Harding R.D. Heterocoagulation in mixed dispersion-effect of particle size, size ratio, relative concentration and surface potential of colloidal components. Colloid and Interface Sci. 1972. V. 10. No. 2. P. 164-173.

64. Kuo J.F., Yen T.F. Some aspects in predicting the point of zero charge of composite oxide systems. Colloid and Interface Sci. 1988. V. 121. No. 1. P. 220-225.

65. Stevenson F.J. Humus Chemistry: Genesis, Composition, Reactions. New York : John Wiley \& Sons, 1994. 512 p. ISBN: 978-0-471-59474-1.

66. Piccolo A. The supramolecular structure of humic substances: a novel understanding of humus chemistry and implications in soil science. Advances in agronomy. 2002. № 75. P. 57-134. DOI: 10.1016/s00652113(02)75003-7. AGR: IND23268553. ISBN 978-0-12-000793-6.

\section{Information about the authors:} Kudriavtsev P. H.,

Doctor of Chemical Sciences, Professor, Deputy Director for Research and Development KUD Industries PN Ltd - Israel Technology Research Center Haifa, Israel

Kudriavtsev N. P.,

Director for Research and Development KUD Industries PN Ltd - Israel Technology Research Center Haifa, Israel 